Universidade de São Paulo

Escola Superior de Agricultura "Luiz de Queiroz"

Identificação e caracterização de genes provenientes de Burkholderia seminalis

$\mathrm{TC3}$.4.2R3 relacionados ao controle da fusariose

Renata Assis Castro

Tese apresentada para obtenção do título de Doutora em

Ciências. Área de concentração: Microbiologia Agrícola

Piracicaba

2018 


\section{Renata Assis Castro}

Ciências Biológicas

Identificação e caracterização de genes provenientes de Burkholderia seminalis TC3.4.2R3 relacionados ao controle da fusariose

versão revisada de acordo com a resolução CoPGr 6018 de 2011

Orientadora:

Profa. Dra. MARIA CAROLINA QUECINE VERDI

Tese apresentada para obtenção do título de Doutora em Ciências. Área de concentração: Microbiologia Agrícola 
Dados Internacionais de Catalogação na Publicação DIVISÃO DE BIBLIOTECA - DIBD/ESALQ/USP

\section{Castro, Renata Assis}

Identificação e caracterização de genes provenientes de Burkholderia seminalis TC3.4.2R3 relacionados ao controle da fusariose / Renata Assis Castro. - - versão revisada de acordo com a resolução CoPGr 6018 de 2011. - - Piracicaba, 2018.

$75 p$

Tese (Doutorado) - - USP / Escola Superior de Agricultura "Luiz de Queiroz".

1. Controle biológico 2. Burkholderia seminalis 3. Fusarium 4. Glutamato sintase 5. Proteína TolB I. Título 
DEDICO

A minha familia (João, Lê e Laura) que fizeram tudo para esta conquista.

$\mathcal{A}$ minha mãe que mesmo na dístâncía estava sempre presente em orações ...

\section{Ofereço}

A minha avó (ín memoria)... desta vez não será como no mestrado. Desta vez não deu tempo de você ouvir meu telefonema dizendo: “Acabou...". Mas você verá aí de cima!!! 


\section{AGRADECIMENTOS}

A minha orientadora, Professora Dra a Maria Carolina Quecine Verdi, pela oportunidade e confiança e pela honra de ser sua primeira aluna a ter o título de Doutora.

Ao Prof. Dr. Welington Luíz de Araújo: o que dizer á você...? se escrevi minha dissertação e agora estou escrevendo minha tese foi pela oportunidade que a quase 12 anos atrás você me deu. Mudou não só a minha vida mas de toda minha família. Nunca conseguirei agradecer à você pelo o que fez por nós. MUITO OBRIGADA...

As amigas Bruna, Carol (chefa) e Jack pela amizade. Nos momentos de escuridão chegavam com lanternas para clarear meu caminho. E nos momentos alegres enchiam mais ainda de cores e flores e muitas risadas nesta caminhada.

A todos os amigos do Laboratório de Genética de Microrganismos: Isa, Carolzinha, Joelma, Helena, Tiago, Bruno, Everton, Daniel, Inês, Letícia, Zezo...e a tantos que passaram e já se foram. A nossa amizade será guardada eternamente.

A Capes, pela concessão de bolsa e financiamento das pesquisas.

A todos os funcionários do Departamento de Genética, que sempre foram solícitos e prontos à ajudar.

A minha família e amigos que sempre me apoiaram nos momentos difíceis e riram comigo nas alegrias.

Á Deus que me dá forças e coragem para continuar na caminhada desta vida. Que esteja comigo, nesta nova etapa... que as nuvens escuras possam logo dar lugar ao céu azul. 
EPÍGRAFE

"Você não sabe o quanto eu caminhei

Pra chegar até aqui

Percorri milhas e milhas antes de dormir

Eu nem cochilei

Os mais belos montes escalei

Nas noites escuras de frio chorei,

A vida ensina e o tempo traz o tom

Pra nascer uma canção

Com a fé do dia a dia encontro a solução Quando bate a saudade eu vou pro mar Fecho os meus olhos e sinto você chegar Você chegar...

Toni Garrido 


\section{SUMÁRIO}

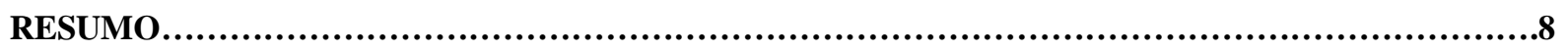

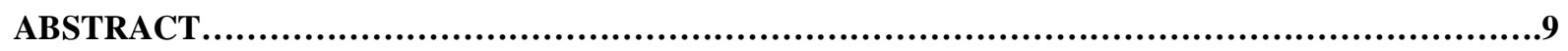

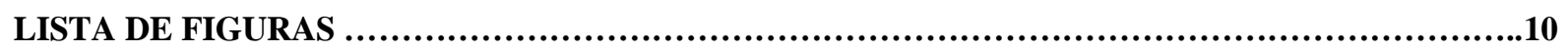

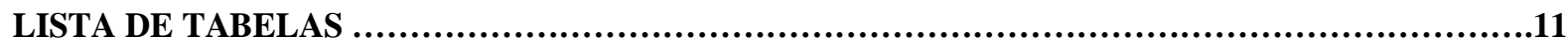

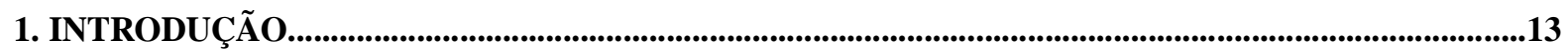

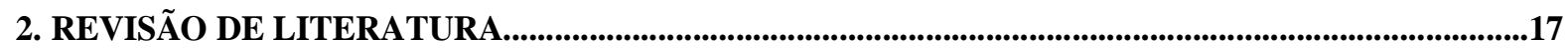

2.1. Doenças fúngicas em plantas causadas pelo gênero Fusarium …………………………...........................17

2.2. Controle biológico e os mecanismos de ação envolvidos no antagosnismo microbiano....................................18

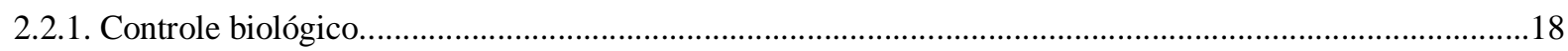

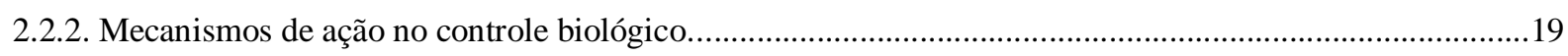

2.3. Utilização de bactérias endofíticas como fonte de novos produtos biotecnológicos........................................20

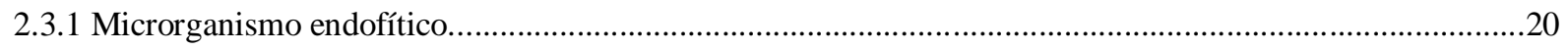

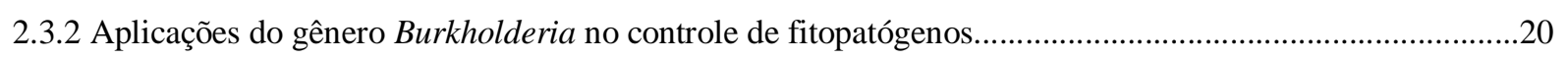

2.4 Metabólitos, peptídeos ribossomais e não ribossomais em microrganismos......................................................22

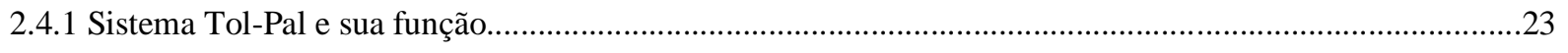

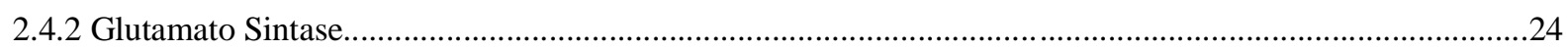

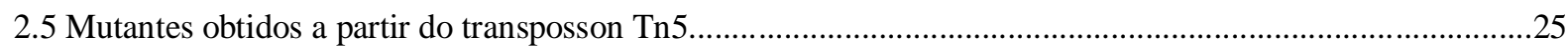

3. JUSTIFICATIVA................................................................................................................................................27

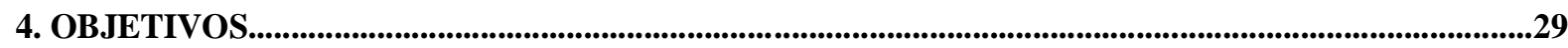

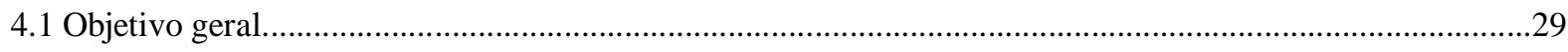

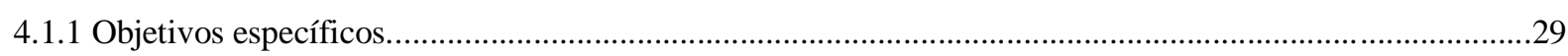

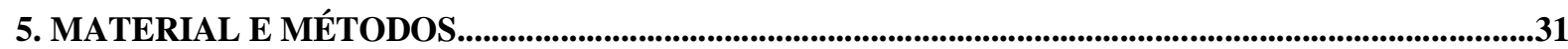

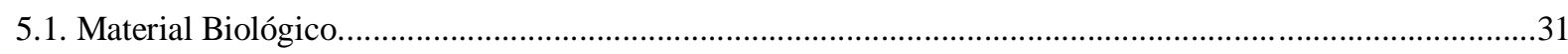

5.2. Atividade antimicrobiana in vitro da linhagem TC3.4.2R3 contra Fusarium spp. ....................................32

5.3 Seleção de mutantes defectivos na inibição de $F$. verticilioides FV-01 CTC ……………………….............33

5.4 Avaliação da produção de compostos antifúngicos termoestáveis pela linhagem TC3.4.2R3 e seus mutantes

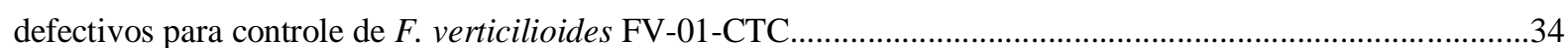

5.5 Avaliação da produção de metabólitos livres de células pela linhagem TC3.4.2R3 selvagem e seus mutantes defectivos pra o controle de $F$. verticilioides FV-01-CTC.

5.6 Avaliação da atividade antagônica de Fusarium spp. pelos mutantes defectivos para F. verticilioides FV-01CTC.

5.7 Caracterização, clonagem e sequenciamento das regiões que flanqueam o transposon em mutantes defectivos

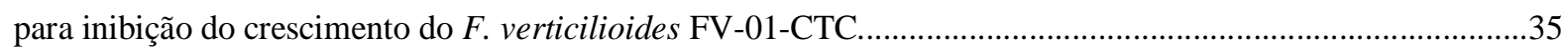

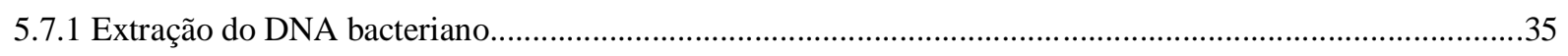

5.7.2 Comprovação da presença do transposon Tn5 nos mutantes selecionados por PCR.....................................36

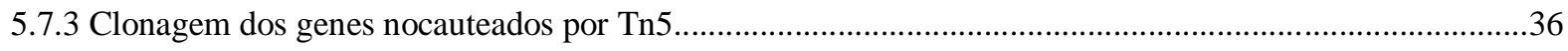

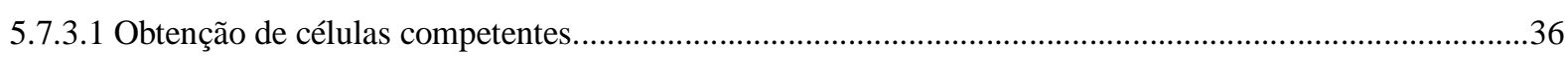


5.7.3.2 Preparo do DNA genômico dos mutantes da linhagem TC3.4.2R3. .37

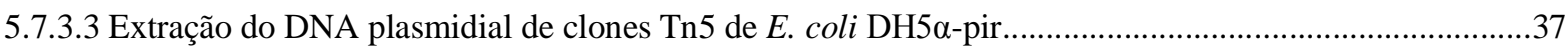

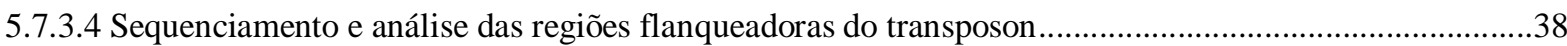

5.7.3.5 Análises in silico dos genes candidatos ao controle da fusariose .......................................................38

5.8 Caracterização dos mutantes defectivos para síntese de glutamato e proteína TolB.....................................39

5.8.1 Característica fisiológica relacionada à curva de crescimento dos mutantes.............................................39

5.8.2 Atividade de antagonismo in vitro dos mutantes com silenciamento para glutamato sintase e proteína TolB

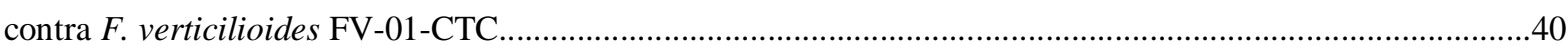

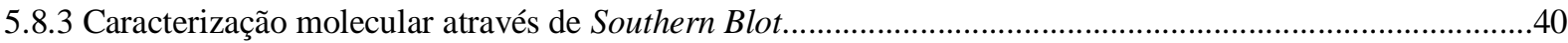

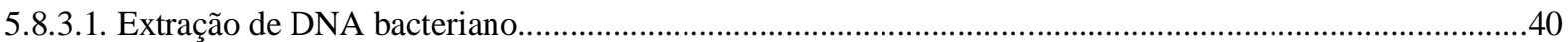

5.8.3.2 Restrição do DNA genômico e transferência para a membrana de náilon..............................................40

5.8.3.3 Preparo da sonda e hibridização molecular......................................................................................41

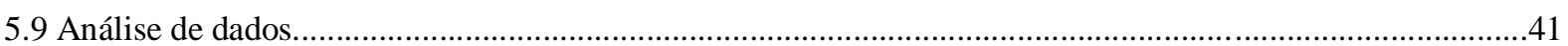

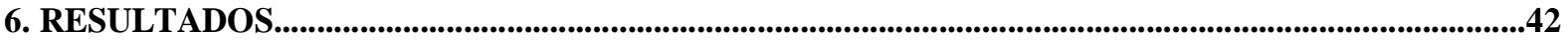

6.1 Antagonismo da linhagem TC3.4.2R3 contra diferentes espécies de Fusarium spp..................................42

6.2 Seleção dos mutantes quanto à perda da capacidade em produzir agentes antimicrobianos por meio do antagonismo

6.3 Caracterização dos compostos produzidos pela linhagem TC3.4.2R3 e seus mutantes defectivos no controle de F. verticilioides FV-CTC -01.....

6.4 Avaliação da atividade antagônica produzida pelos mutantes defectivos contra Fusarium sp......................44

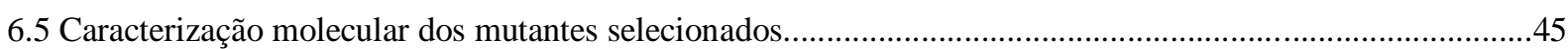

6.5.1 Confirmação da inserção do transposon Tn5 por análise de PCR .........................................................45

6.5.2 Clonagem, sequenciamento e análise das regiões flanqueadoras do transposon Tn5................................45

6.6 Análises in silico dos mutantes M15, M17 e M28 da linhagem TC3.4.2R3 ............................................47

6.7Análise in silico de metabólitos secundários produzidos por Burkholderia seminalis linhagem TC3.4.2R3

6.8 Caracterização dos mutantes para glutamato sintase e TolB avaliados na inibição do crescimento do patógeno $F$. verticilioides $F V$-01-CTC...

6.8.1 Comparação da curva de crescimento entre a linhagem TC3.4.2R3 selvagem e seus mutantes em tempo determinado.

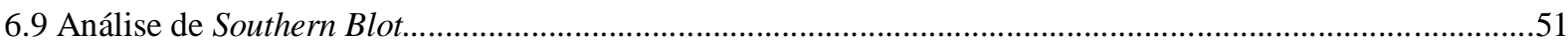

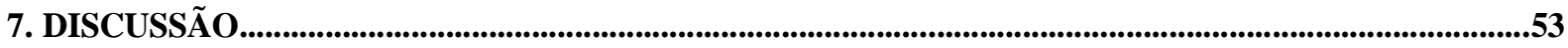

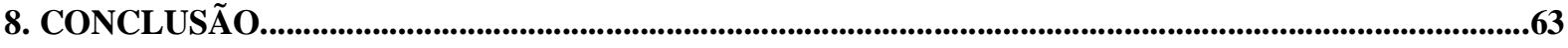

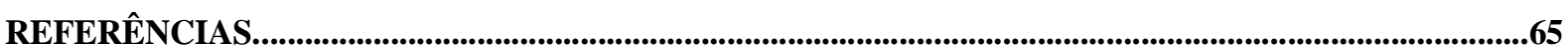


RESUMO

\title{
Identificação e caracterização de genes provenientes de Burkholderia seminalis TC3.4.2R3 relacionados ao controle da fusariose
}

\begin{abstract}
$\mathrm{Na}$ agricultura moderna, formas alternativas de alcançar maior produtividade de modo sustentável são prioridades. Entretanto, o sucesso agrícola é ainda excessivamente dependente do emprego de fertilizantes químicos e de defensivos agrícolas. A severidade de algumas doenças é um fator preocupante na produção de várias culturas. Dentre alguns patógenos de planta, destaca-se o gênero Fusarium, o qual apresenta uma expressiva importância na agricultura por ser patógeno em várias culturas de interesse econômico.. Por outro lado, a utilização de microrganismos endofíticos como agentes de biocontrole vem se tornando cada vez mais atrativa, pois, surge como uma alternativa capaz de amenizar gastos excessivos com controle químico e danos ao meio ambiente. Dentre esses microrganismos, destaca-se o gênero Burkholderia, conhecidamente capaz de produzir uma vasta gama de antimicrobianos, com diferentes níveis de especificidade. Essas bactérias vivem em interações com diversos microrganismos e plantas, em um ambiente altamente competitivo, resultando em uma fonte de metabólitos secundários, bacteriocinas dentre outros pepitideos A linhagem TC3.4.2R3 Burkholderia seminalis, isolada endofiticamente de raízes de cana-de-açúcar, é capaz de controlar vários fungos e bactérias fitopatogênicas. Apartir dessa linhagem foi construída uma biblioteca de mutantes randômicos por meio de transposon. Assim, por meio dessa biblioteca, o objetivo do trabalho foi selecionar mutantes defectivos no controle de diferentes espécies de Fusarium, identificar e caracterizar os genes nocauteados, visando o melhor entendimento do controle da fusariose. Os resultados obtidos por meio da caracterização do teste de antagonismo demonstrou que a linhagem TC3.4.2R3 selvagem produz metabólitos capazes de inibir in vitro o crescimento de Fusarium spp. A partir da biblioteca de mutantes, foram obtidos 8 mutantes defectivos para o controle de Fusarium verticilioides FV-01-CTC que não apresentaram alta especificidade quando avaliados contra outros Fusarium spp. Dentre os genes nocauteados foram identificadas sequências codificadoras para a proteína glutamato sintase, TolB e FAD. Até o momento não foi encontrado relatos sobre o glutamato como um biocontrolador de patógenos, entretanto o uso de mutantes sítio dirigido para esse gene confirmou o papel do mesmo no controle de FV-01-CTC. TolB é uma proteína relacionada ao transporte de substâncais e pode ter seu papel de controle relacioanado à secreção de metabolítos secundários, visto que in silico, no genoma da TC3.4.2R3, foram encontrados 18 clusters resposáveis pela produção de metabólitos secundários. Assim, o presente trabalho abre novas perspectivas de estudo, visto que, os mecanismos de controle da fusariose por B. seminalis TC3.4.2R3 são amplos e sinergisticos. Há uma enorme perspectiva em desvendar o papel do glutamato e TolB no controle de fitopatógenos. Os mutantes caracterizados, pode ser fonte de novos estudos para o complexo entendimento da interação microrganismo-planta-patógeno, visto que há a possibilidade de verificar por exemplo o papel do glutamato proveniente da linhagem TC3.4.2R3 na promoção de crescimento vegetal.
\end{abstract}

Palavras-chave: Controle biológico; Burkholderia seminalis; Fusarium; Glutamato sintase; Proteína TolB 


\section{ABSTRACT \\ Identification and characterization of Burkholderia seminalis TC3.4.2R3 genes related to the control of fusariosis}

In modern agriculture, alternative ways of achieving high productivity with sustainability are priority. However, agricultural success is still excessively dependent on the use of chemical fertilizers and pesticides. The severity of some diseases are worrying factor in the production of differents crops. Among plant pathogens, the genus Fusarium stands out, which has an important role in agriculture being disease causer in several crops such as: sugarcane, corn, passion fruit, tomato, banana, rice, and others. Fusarium can be found inhabiting soil in the most diverse geographical regions of the world, especially in tropical and subtropical climates. On the other hand, studies using endophytic microorganisms as biocontrol agents has become increasingly attractive, since they appear as an alternative to chemical control. Among these microorganisms, the genus Burkholderia stands out. This genis is able to produce a wide range of antimicrobials, with different levels of specificity. Moreover, Burkholderia has been received special attention because its potential plant growth promoter, bioremediation agents and recent studies aimed at biocontrol of diseases. These bacteria live in interactions with diverse microorganisms and plants in a highly competitive environment representing significant source of new bioactive secondary metabolites, bacteriocins among other pepitides. The $B$. seminalis strain TC3.4.2R3, endofitically isolated from sugarcane roots, is able to control diverse phytopathogenic fungi and bacteria. By Tn5 randomic mutations, it was obtained a library of TC3.4.2R3 mutantes. Thus, using this library, the objective of this work was select defective mutants to control of Fusarium spp., with the aimed the better understand the fusariose control by identificayion and characteriazation of knockouted genes. The results obtained through the characterization of the antagonism assays allowed us to conclude that wild-type TC3.4.2R3 produces many metabolites with antifungal activity under in vitro conditions, being able to control the growth Fusarium spp. From the mutants library we found 8 defectives mutants to control of F. verticilioides FV01-CTC. Among the knockouted genes we found sequences enconding glutamato syntase, TolB and FAD. To date no reports have been found on glutamate as a pathogen biocontroller, however the use of mutant site directed to this gene confirmed the role of the same in the control of FV-01-CTC. TolB is a protein related to the transport of substances and may have its biocontrol role related to the secretion of secondary metabolites, since in silico analisys in the genome of TC3.4.2R3, 18 clusters were found as responsible for the production of secondary metabolites. Thus, the present work opens new perspectives of study, confirming that the mechanisms of control of fusariosis by $B$. seminalis TC3.4.2R3 are ample and synergistic. There is a huge prospect in unraveling the role of glutamate and TolB in controlling of plant pathogens. The characterized mutants may be the source of new studies for understanding the complex interaction among microorganism-plant-pathogen, since it is possible to verify, for example, the role of glutamate from the TC3.4.2R3 strain in the plant growthpromotion.

Keywords: Biological control; Burkholderia seminalis; Fusarium; Glutamate synthase; TolB protein 


\section{LISTA DE FIGURAS}

FIGURA 1: O sistema Tol-Pal. Em de Escherichia coli o TolA consiste em três domínios (I,II,III) que ligam o IM e OM através de interações proteína-proteína com TolR e TolQ na membrana interna e o ToiB e Pal no periplasma. ColA liga-se a BtuB através do seu domínio de ligação ao receptor central, e em seguida, recruta OmpF como um translocador através da membrana externa. O domínio $\mathrm{N}$-terminal de ColA insere-se através ou em torno de OmpF e interage com a TolA e TolB......

FIGURA 2: Esquema do ensaio de inibição do crescimento de Fusarium spp. pela linhagem selvagem $B$. seminalis TC3.4.2R3

FIGURA 3: Esquema da seleção de mutantes defectivos para inibição do crescimento de Fusarium verticilioides $\mathrm{FV}-01-\mathrm{CT}$......

FIGURA 4: E Esquema proposto para verificação da inibição do crescimento de $F$. verticilioides FV-01-CTC pela linhagem selvagem TC3.4.2R3 e seus mutantes (esquerda). Fórmula utilizada para a avaliação do índice de inibição dos mutantes (direita).

FIGURA 5: Diferentes níveis de inibição da linhagem Burkholderia seminalis TC3.4.2R3 sobre alguns fungos fitopatógenicos avaliados.

FIGURA 6: Antagonismo in vitro por pareamento da linhagem TC3.4.2R3 selvagem e seus mutntes contra o fitopatogeno $F$. verticilioides FV-01-CTC. A taxa de inibição foi mensurada após 7 dias de inoculaão bacteriana $\left(10^{8}\right.$ UFC. $\left.\mathrm{mL}^{-1}\right)$. A taxa de inibição foi a média do crecimento da colônia sendo avaliadas 4 repetições (placas). Tratamentos com a mesma letra não diferem estatisticamnte $(P>0,05)$ de acordo com o teste de Tukey. .43

FIGURA 7: Amplificação da região do trasnposon com os primers Tn5F e Tn5R ) (WANG et al., 2008) a partir do DNA extraído dos 8 transformantes da linhagem B. seminalis TC3.4.2R3 que apresentaram alteração na atividade antifúngica. $\mathrm{O}$ transposon Tn5 extraído de E. coli DH5 $\alpha$-pir:Tn5 foi utilizado como controle positivo. Não houve amplificação no DNA genomico da linhagem selvagem. O marcador de pares de base 100pb e o marcador de peso molecular $1 \mathrm{~Kb}$ estão posicionados na lateral a esquerda do gel de agarose. A ordem das amostras da esquerda para a direita é: M3, M9, M15, M17, M20, M21, M25, M28 (mutantes), selvagem, TN5 e controle da reação de PCR.

FIGURA 8: DNA plasmidial contendo o transposon Tn5 extraído de células de $E$. coli DH5 -pir e enviadas para sequenciamento a jusante e a montante utilizando os primers KANFP-1 e KANRP-2 que anelam nas extremidades do transposon.

FIGURA 9: Avaliação do teste de antagonismo por pareamento in vitro da linhagem selvagem e dos mutantes M15 e M17 obtidos por meio da inserção do transposon Tn5, e pelos mutantes obtidos por troca alélica cepa com silenciamento do gene do glutamato (MR3) e a cepa com o gene silenciado mais sua complementariedade (2gg) contra o fungo F. verticilioides FV-01-CTC. A taxa de inibição foi mensurada após 7 dias de inoculação e a média do crescimento da colônia foi avaliadas 4 repetições (placas). Tratamentos com a mesma letra não diferem estatisticamente $(P>0,05)$ de acordo com o teste de Tukey.....

FIGURA 10: Curvas de crescimento da linhagem TC3.4.2R3 selvagem e seus mutantes em meio cultura LB. Sendo suplementado d seguinte forma: M15 e M17 suplementado com canamicina $100 \mu \mathrm{g} / \mathrm{mL}$; MR3 foi suplementado com $50 \mu \mathrm{g} / \mathrm{mL}$ de cloranfenicol; e o mutante $2 \mathrm{gg}$ suplementdo com $50 \mu \mathrm{g} / \mathrm{mL}$ de cloranfenicol mais $200 \mu \mathrm{g} / \mathrm{mL}$ de canamicina. Os dados mostrados são representativos de 3 repetições por tratamento sendo a leitura realizada em espectrofotômetro a uma $\mathrm{OD}_{600} \mathrm{~nm}$ em diferentes tempos. 


\section{LISTA DE TABELAS}

TABELA 1: Linhagens fitopatogênicas do gênero Fusarium utilizadas nos ensaios de antagonismo. 32

TABELA 2: Caracterização dos mutantes defectivos para a inibição de diferentes espécies de Fusarium quanto à capacidade de produzir agentes microbianos.

TABELA 3: Caracterização dos mutantes defectivos para a inibição de diferentes espécies de Fusarium quanto à capacidade de produzir agentes microbianos.

TABELA 4: Análise das regiões flanqueadoras do transposon de mutantes de B. seminalis TC3.4.2R3, que apresentaram defectividade no controle do crescimento do F. verticilioides FV-01-CTC...

TABELA 5: Descrição da identidade do gene mutato correspondente a glutmato sitase em diferentes bancos de dados glutamato sintase.

TABELA 6: Descrição da identidade do gene mutado correspondente a proteína TolB em diferentes bancos de dados.

TABELA 7: Clusters gênicos de metabólitos secundários de Burkholderia seminalis TC3.4.2R3 obtidos por meio do banco de dados antiSMASH (Antibiotics SecondaryMetabolic Analysis Shell).... 


\section{INTRODUÇÃO}

Dados obtidos pelo Institut National D'etudes Demographiques (INED) e pela Food and Agriculture Organization (FAO) apontam que a população mundial em 2016 era de aproximadamente 7,4 bilhões de pessoas. Pelas estimativas realizadas para os próximos anos espera-se que em 2025, teremos em torno de 8,1 bilhões de pessoas, chegando à 9,6 bilhões em 2050 (CARRER et al., 2010). Com uma preocupação eminente, a FAO em janeiro de 2015, alertou que se o crescimento desordenado de consumo permanecer, em 2050 o mundo precisará de $60 \%$ mais alimentos e $40 \%$ mais água (ALEXANDRATOS et al., 2012). Dados publicados pela OECD-FAO (2015) mostram que o Brasil tem a quinta maior população (acima de 200 milhões) e a quinta maior superfície em extensão territorial com áreas férteis e clima favorável ao desenvolvimento de diversas culturas agrícolas e pecuária. Entretanto, nas últimas décadas o agronegócio em todo mundo está em estado de alerta: safra após safra vem sendo observado perdas na produtividade devido a pragas e doenças (ASHRAF et al., 2013). Mesmo com os avanços tecnológicos, doenças e pragas são responsáveis por prejuízos bilionários, afetando toda a cadeia produtiva, chegando até ao consumidor. Como exemplo, estudos recentes apontam uma perda média anual de até $7,7 \%$ da produção agrícola brasileira, o equivalente a 25 milhões de toneladas (TREMACOLDI 2010; LOPES-DA-SILVA et al., 2015; OECD-FAO, 2015), e nesse contexto, destaca-se as doenças fúngicas.

Dentre os fungos de grande importância para a agricultura mundial, podemos citar os fungos pertencentes ao gênero Fusarium. Esses patógenos podem ser encontrados habitando o solo, nas mais diversas regiões geográficas do mundo (SHUPING \& ELOFF, 2017). Diferentes culturas de grande interesse econômico mundial como feijão (MACEDO et al., 2017), milho (PEREIRA et al., 2017), arroz (JUNG et al., 2018), soja (SAHU et al., 2017) e cana-de-açúcar (HILTON et al., 2017), são acometidas por doenças causadas por diferentes espécies de Fusarium. Em muitos casos, não há um controle químico viável para seu controle, pois além de oneroso economicamente, pode apresentar restrições do ponto de vista ambiental, por se tratar de um patôgeno de solo (DORDEVIĆ et al., 2012; CARRER FILHO et al., 2015)

Em cana-de-açúcar, a fusariose pode ocasionar uma grande variedade de sintomas nas plantas, que dependem do estágio de desenvolvimento da cana-de-açúcar, do seu nível de resistência e das condições ambientais. Em plântulas de cana-de-açúcar os sintomas são: sistema radicular pouco desenvolvido; baixo vigor; podridão de raiz e de colo; damping-off (morte de várias plântulas agrupadas, denominadas reboleira). Em toletes de plantio, os sintomas são: baixa brotação das gemas; podridão de raíz; enfezamento (redução no tamanho) dos brotos. Nos 
colmos os sintomas são muito parecidos com os da podridão vermelha e seu aparecimento está associado a ferimentos químicos ou físicos como aqueles causados por brocas (ROSSETTO \& SANTIAGO, 2007). Outro dano causado é o chamado Pokkah-Boeng, em que ocorre uma deformação do topo da cana-de-açúcar. Essa doença, causada pelo fungo F. verticilioides, está amplamente espalhada pelas áreas de cultivo de cana-de-açúcar ao redor do mundo (HILTON et al., 2017). Embora não seja uma das doenças mais importante dos campos brasileiros essa doença pode causar grandes perdas na produção.

Além disso, Fusarium spp. produz um amplo espectro de micotoxinas (CHELKOWSKI, 1989), as quais resultam em diversos efeitos nocivos para a saúde humana e animal (JOFFE, 1986; GUPTA, et al., 2000). Durante o ciclo saprofítico e parasítico de vida, o Fusarium spp. é exposto a vários metabólitos tóxicos, incluindo metabólitos antifúngicos produzidos por microrganismos que coabitam o mesmo nicho (LAGOPODI, et al., 2002; QUECINE et al. 2016). Todavia, Fusarium spp. pode tolerar ou combater os metabólitos tóxicos e então ser capaz de se propagar, colonizar e infectar as plantas (SCHOUTEN, et al., 2004). Assim, a busca por compostos e ou novas práticas de manejos que possam inibir o crescimento deste fitopatógeno é de suma importância para agricultura global, sendo uma opção a utilização de produtos obtidos a partir de microrganismos (TAN et al., 2013).

É sabido que o interesse no emprego de microrganismos em práticas agrícolas aumentou significativamente nos últimos anos, pois tanto na área de promoção de crescimento vegetal, como no controle biológico de pragas e doenças de plantas, eles apresentam-se como potenciais substitutos à produtos químicos, sendo uma alternativa menos honerosa tanto economicamente como ambientalmente (LUCY et al., 2014).

Dentre esses microrganismos, bactérias do gênero Burkholderia têm sido descritas como um dos grupos mais importantes encontrados no interior das raízes e associada a rizosfera, vivendo comensalmente em uma íntima associação com plantas de interesse agrícola (MENDES et al., 2007; LUVIZOTTTO et al., 2010; SUÁREZ-MORENO et al., 2012; ANDREOTE et al., 2014; LOPES et al., 2016). Este gênero é caracterizado por apresentar grande versatilidade nutricional, podendo metabolizar diferentes fontes orgânicas de carbono. Essa capacidade reflete em sua habilidade em colonizar os mais variados nichos e produzir diversos compostos (MENDES et al., 2007). O gênero Burkholderia apresenta-se descrito na literatura em diferentes contextos de aplicação no manejo agrícola, podendo ser aplicado em biocontrole, para processo de biodegradação e biorremediação, como promotora de crescimento vegetal, demonstrando assim sua importância ecológica e biotecnologica (VIAL et al., 2007; DE SOUZA et al., 2013; MOREIRA et al., 2016). O antagonismo por Burkholderia spp.(principalmente contra fungos 
fitopatogênicos e oomicetos) é bem estabelecido devido há diferentes compostos metabólitos produzidos por este gênero (DA SILVA ARAÚJO et al., 2017). Dentre alguns compostos destacamos pirrolnitrina (EL-BANNA et al., 1998; HWANG et al., 2002), fenazinas (CARTWRIGHT et al., 1995), cepacidine A (MAO et al., 2006; DA SILVA ARAÚJO et al., 2017), cepaciamides A (JIAO et al., 1996), sideróforos (TYRRELL et al., 2015) entre outros.

A linhagem endofítica identificada como Burkhoderia seminalis TC3.4.2R3 foi isolada de raízes de cana de açúcar (LUVIZOTTO et al., 2010), foi descrita como uma bactéria de grande potencial biotecnológico devido sua capacidade de solubilização de fosfato, produção de sideróforos, produção de ácido indolacético (AIA), dentre outros mecanismos. Além disso, em estudos realizados por Araújo et al., (2016), com a mesma linhagem foi capaz de inibir o crescimento do fitopatógeno Burkholderia gladioli (o qual causa necrose em de plantas de orquideas) por meio de sua capacidade de produção de metabólitos antimicrobianos.

Visando compreender os mecanismos genéticos relacionado as habilidades demonstradas por essa linhagem, seu genoma foi recentemente sequenciado (acesso LAEU01000000). Foram obtidas informações referente à mecanismos importantes para a compreensão da interação dessa linhagem com plantas. Foram encontrados clusters gênicos para pirrolnitrina, para biossíntese de AIA, para a degradação de etileno via ACC desaminase, entre outros, demonstrando que a associação microrganismo-planta esta diretamente relacionado a sua capacidade de produção de hormônios vegetais, além de apresentar capacidade de ação antifúngica (ARAÚJO et al. 2016).

É notório o grande potencial biotecnológico que esta linhagem apresenta como biocontroladora de diversos patógenos. Contudo é necessário um estudo direcionado para o funcionamento do mescanismos de ação dos genes que causam este controle a fim de comprovar a atividade direta da bactéria. Assim, o objetivo deste trabalho foi identificar os genes de $B$. seminalis (TC3.4.2R3) e sua caracterização visando o melhor entendimento dos mecanismos envolvidos no controle da fusariose. 


\section{REVISÃO DE LITERATURA}

\subsection{Doenças fúngicas em plantas causadas pelo gênero Fusarium}

Desde que os seres humanos começaram a cultivar plantas, as doenças fúngicas têm sido uma das principais causas de perdas nas culturas. Com a crescente demanda por alimentos, devido ao crescimento populacional desordenado, cada vez mais é necessário o aumento da produtividade das culturas agrícolas e de áreas de plantio. No entanto, mesmo com os avanços tecnológicos os fitopatógenos, insetos pragas e plantas daninhas continuam a ser sérios problemas na área agrícola (TREMACOLDI 2010; OECD-FAO, 2015).

O gênero Fusarium apresenta uma expressiva importância na agricultura por ser patógeno em várias culturas de interesse econômico tais como: maracujá (FLORES et al., 2012), tomate (MCGOVERN, 2015), banana (FORTUNATO et al., 2012; HO et al. 2015), cana-de-açúcar (GOSWAMI et al., 2014), milho (LANUBILE et al., 2014), dentre outras.

Este gênero pode ser encontrado habitando o solo, nas mais diversas regiões geográficas do mundo com características de clima tropical e subtropical. É capaz de sobreviver por longos períodos no solo pela formação de estruturas chamadas clamidósporos, podendo colonizar ramos, folhas, inflorescência e frutos através de seus conídios que são disseminados pelo ar ou pela água de irrigação e até mesmo pelo uso de implementos agrícolas que contenham propágulos do fitopatógeno (DAVIS et al. 2006).

O gênero Fusarium é caracterizado pelo seu crescimento rápido, colônias com coloração pálida ou colorida (violeta à púrpura escuro ou do creme ao laranja), com micélio aéreo e difuso (DOMSH et al., 1980). Sua variabilidade morfológica tem gerado controvérsia na taxonomia e classificação das espécies de Fusarium devido a fatores como perda de características morfológicas, variação e mutação dentro da cultura, dificultando a criação de um sistema taxonômico (GEISER et al., 2004), bem como a busca de biomoléculas específicas para seu controle.

Desde 1900, aproximadamente 1000 espécies de Fusarium foram descritas, a maioria pelas características das suas estruturas (esporodóquios), diretamente nos hospedeiros ou substratos naturais, o que levou a que muitas dessas espécies fossem consideradas sinônimas, tendo em vista a grande variabilidade deste fungo em diferentes ambientes e substratos (LESLIE \& SUMMERELL, 2008).

A complexa comunidade microbiana que habita a rizosfera interage com os patógenos de solo e influenciam, consequentemente, a infecção pelos fungos. $\mathrm{Na}$ rizosfera, além dos microrganismos patogênicos, também existem fungos e bactérias que possuem atividade 
antagonística contra fitopatógenos. Eles podem afetar adversamente densidades de populações dinâmicas temporais e espaciais, atividades metabólicas de patógenos de solo a partir da produção de metabólitos antimicrobianos secundários como micotoxinas, enzimas líticas, entre outros (RAAIJMAKERS et al., 2009).

Como exemplo, a fusariose em milho, vem sendo controlada através do uso de vários tipos de fungicidas (muitas vezes usados em consórcios) que são aplicados tanto nas sementes, como na área foliar. Ambos demonstraram eficiência na redução da incidência da doença em milho (LASCA et al., 2005). Este resultado vem reforçar que o controle químico da fusariose é possível, porém temos que considerar o alto custo dos insumos químicos utilizados e o prejuízo causado ao meio ambiente. Assim, se faz necessário encontrar uma alternativa contra a doença que seja menos danosa ao meio ambiente e honerosa ao produtor consequentemente ao consumidor.

\subsection{Controle biológico e os mecanismos de ação envolvidos no antagonismo microbiano}

\subsubsection{Controle biológico}

O desenvolvimento de doenças infecciosas é caracterizado por uma série de eventos que ocorrem de maneira ordenada. Estes eventos incluem a sobrevivência, disseminação, infecção, colonização e reprodução do patógeno, como um ciclo das relações patógeno-hospedeiro (AGRIOS et al., 2005).

O controle biológico tem como premissa básica, manter a densidade populacional das espécies de pragas associadas a agricultura, em níveis economicamente e ecologicamente aceitáveis. Em um conceito mais amplo Cook \& Baker (1983) definiu controle biológico como "redução da soma de inóculo ou das atividades determinantes da doença, provocada por um patógeno, realizada por um ou mais organismos que não o homem.” Já Freitas et al. (2005), tem como base o conceito de Cook \& Baker (1983), porém com uma visão mais atual e direta, diz que o controle biológico visa reduzir a densidade do inóculo ou a atividade de um patógeno, excluir da planta hospedeira ou suprimir o patógeno após ter ocorrido a infecção.

No cenário agrícola atual, o controle de algumas doenças é visto como uma grande dificuldade. Cada vez mais se torna um desafio obter o controle de doenças devido à demanda por produtos livres de resíduos químicos e pela percepção da sociedade em geral, sobre o impacto das práticas que são utilizadas no controle de doenças, como o uso excessivo de agrotóxicos e suas consequências para a saúde dos seres humanos e para o meio ambiente (PUNJA \& UTKHEDE, 2003). Desta forma, levando em consideração os custos financeiros e 
ambientais, agricultores e pesquisadores começaram a considerar o uso de métodos alternativos no combate às doenças.

\subsubsection{Mecanismos de ação no controle biológico}

O desenvolvimento de produtos a base de microrganismo visando controle biológico de doenças em plantas, tem sido uma alternativa fundamental, especialmente no contexto do manejo integrado de pragas e doenças, principalmente quando empregada com outros métodos de controle, apresentando baixo custo e pouca agressividade ao ecossistema (SILVA et al., 2004; TAN et al., 2013).

O controle biológico pode ocorrer de maneira direta, quando o antagonismo envolve o antagonista-patógeno, ou indiretamente, quando envolve patógeno-planta-antagonista por meio de indução de resistência (DUFFY; KEEL; DÉFAGO 2004).

Mais detalhadamente, Romero et al. (2007) classificou alguns mecanismos de ação em antagonismo direto e indireto:

Antagonismo direto: a) produção de substâncias antimicrobianas (antifúngicos, antibióticos e bacteriocinas); b) competição por nutrientes; c) competição por nichos; d) produção de compostos antimicrobianos voláteis; e) detoxificação (degradação de substâncias tóxicas produzidas pelo patógeno); f) hiperparisitismo (bacteriófagos, vírus que infectam bactérias e podem levar a morte bacteriana); g) predação e parasitismo (visto geralmente em actinomicetos); h) produção de enzimas líticas (quitinases, $\beta$-1,3-glucanases dentre outras); i) produção de toxinas; j) silenciamento gênico do competidor (envolve substâncias químicas que podem modular ou bloquear a síntese de agentes antimicrobianos ou enzimas, através do silenciamento gênico.); 1) interferência no fenômeno quorum sensing (acil-homoserina lactonas, moléculas sinalizadoras produzidas pelas bactérias que modulam a expressão de genes); m) produção de sideróforos (sequestro ou quelação do ferro).

Antagonismo indireto: certas bactérias são capazes de disparar um fenômeno de resistência na planta através de sua indução após exposição à elicitores, sendo eles abióticos ou bióticos, de forma que ocorra a resposta imediata dos tecidos, que reagem mais eficientemente as tentativas de colonização pelo patógeno.

O controle por indução de resistência da planta é dito como indireto porque envolve também o hospedeiro. Este mecanismo se divide em duas categorias distintas: SAR (resistência sistêmica adquirida) - quando a planta ativa com eficácia o mecanismo de resposta à infecção primária por um patógeno; e ISR (resistência sistêmica induzida) - não ocorre o acúmulo de 
produção de proteínas como na SAR, sendo mediada por uma rota de sinalização de jasmonato/etileno não apresentando fenótipo de doença a planta. No entanto, a elucidação dos mecanismos de ação muitas vezes é dificultada devido à complexa interação patógenohospedeiro-antagonista.

Com tantas possibilidades, se faz necessário estudos mais aprofundados para melhor elucidação sobre os mecanismos de ação de agentes de biocontrole, para a obtenção de linhagens antagônicas mais efetivas e o desenvolvimento de métodos de produção e formulação mais consistente, que aumente a atividade antagonística e que cumpram requisitos, de pacotes toxicológicos e de registro, necessários para o desenvolvimento de um produto comercial.

\subsection{Utilização de bactérias endofíticas como fonte de novos produtos biotecnológicos}

\subsubsection{Microrganismo endofítico}

Endófitos podem ser definidos como microrganismos que colonizam os tecidos internos da planta sem causar danos visíveis ao hospedeiro e sem produzir estruturas externas visíveis, ocorrendo principalmente nas folhas, ramos e raízes sem causar danos às mesmas (AZEVEDO \& ARAÚJO, 2007).

As bactérias endofíticas foram descobertas por Darnel em 1904 (TAN \& Zou, 2001) e desde então tem sido isolados de diversas plantas hospedeiras, incluindo as de grande interesse agronômico. São frequentemente encontradas em todas as plantas estudadas, (até o momento), colonizando seus tecidos internos e podendo estabelecer uma variedade de interações mutualísticas, comensais e simbióticas como o controle de fitopatógenos.

A capacidade de bactérias endofíticas atuarem no controle biológico pode ser resultado de vários fatores, como produção de antibióticos, promoção de crescimento e indução de resistência sistêmica (MADHAIYAN et al., 2004). Produtos antimicrobianos produzidos por bactérias endofíticas têm se apresentado como importantes alvos de estudo, pois representam um reservatório de novos compostos ainda não explorados (BRADER et al., 2014).

\subsubsection{Aplicações do gênero Burkholderia no controle de fitopatógenos.}

O gênero Burkholderia compreende bactérias Gram-negativas, aeróbicas, não formadoras de esporos, taxonomicamente pertencente à subdivisão $\beta$-proteobactéria. O gênero compreende 65 espécies válidas segundo a Lista de Nomes Bacterianos Aprovados (DSMZ, 2017). Possui 
grande versatilidade nutricional, capaz de metabolizar mais de 200 diferentes fontes orgânicas de carbono, refletindo na sua capacidade em habitar os mais variados nichos. Pode ser linhagens de solos, da rizosfera de inúmeras culturas agrícolas, de ambientes hospitalares, da água (incluindo água do mar), além de várias espécies de plantas, animais e humanos (PARKE \& GURIANSHERMAN, 2001).

Bactérias deste gênero também já foram utilizadas no manejo agrícola, para o biocontrole, biodegradação/biorremediação e promoção do crescimento vegetal (PERIN et al., 2006). Embora alguns membros do gênero Burkholderia sejam patógenos ou associados com algumas doenças em seus hospedeiros, a grande maioria das espécies associadas às plantas não são patogênicas e podem apresentar uma interação neutra ou benéfica com seus hospedeiros. Resultados com experimentos em campo utilizando bactérias do gênero Burkholderia demonstraram a capacidade dessas bactérias em colonizar a rizosfera de milho, trigo, arroz, ervilha, girassol e rabanete, aumentando significativamente o crescimento da planta hospedeira, além de reduzir a presença de patógenos (CHIARINI et al., 2006).

O controle biológico utilizando Burkholderia poderia substituir parcialmente a utilização de pesticidas químicos comuns, como captan, thiran, PCNB, benomil e tiabendazol, assim como fumigantes, como brometo de metila (composto químico com alto potencial de destruição do ozônio), cloropicrin e todos os fungicidas ou biocidas de amplo espectro (PARKE \& GURIANSHERMAN, 2001).

Agentes antimicrobianos são substâncias orgânicas que podem combater ou inbir o crescimento de outros organismos. Tem sido utilizado para o controle de doenças de origem bacteriana e fúngica em diferentes culturas. Apresentam baixo peso molecular e em pequenas concentrações, podem ser deletérias ao crescimento ou a atividade metabólica de outros microrganismos (MAIA et al., 2009).

Há uma grande variedade de compostos com atividade antimicrobiana associada a esse gênero: cepacinas, pirrolnitrinas, cepaciamidas, cepacidinas, alteridinas, quinolonas, fenazinas, sideróforos e lipopeptídeos, em sua maioria, compostos com atividade antifúngica (PARKER et al., 1984; HWANG et al., 2002; MAO et al., 2006). No entanto, a especificidade desses metabólitos quanto ao controle de patógenos do gênero Fusarium ainda não estão bem compreendidos.

A detecção da produção de pirrolnitrina, por exemplo, por uma linhagem de B. cepacia B37w esteve associada à inibição dos sintomas da seca da raiz por Fusarium sambucinum (BURKHEAD et al., 1994). Bevinino et al. (2000) observaram que a linhagem de B. cepacia MC17, já descrita como excelente agente promotor de crescimento de plantas de milho, foi também 
capaz de controlar a infestação pelo fungo F. verticilioides nos estágios iniciais de crescimento da planta, fase em que é observada uma maior densidade da bactéria (NACAMULLI et al., 1997). O trabalho realizado por Mendes et al. (2007) constatou que a B. cepacia é o endófito cultivável mais abundante na rizosfera de cana-de-açúcar e que é eficiente no controle in vitro do fungo F.verticilioides, causador da Pokkea Boeng, uma das doenças mais frequentes que causa perdas na produção comercial em plantações de cana-de-açúcar e milho.

Frente a sua alta versatilidade, o interesse e a importância em estudos com as espécies do gênero se justifica, pois apresenta grande potencial para novas abordagens e futuras aplicações (LUVIZOTTO et al., 2010; ARAÚJO et al., 2016).

\subsection{Metabólitos, peptídeos ribossomais e não ribossomais em microrganismos}

O conjunto de processos metabólicos que desempenham função associada ao crescimento celular microbiano está relacionado com metabolismo primário, onde os principais metabólitos são enzimas, ácidos orgânicos entre outros (BROGDEN, 2005). Em muitos microrganismos têm sido observada a produção de compostos orgânicos que não estão envolvidos diretamente com o crescimento e reprodução. Estes compostos podem ser gerados no início ou final da fase de crecimento da bactéria e são conhecidos como metabólitos secundários ou peptídeos (MOFFITT \& NEILAN 2001; BROGDEN, 2005).

Esses peptídeos podem ser sintetizados por duas vias: ribossomal envolvendo a produção de peptídeos por todas as espécies vivas, incluindo bactérias que participam do sistema de defesa do hospedeiro conhecidos também como pepitideos ribossomais (PKSs), boa parte deles atuando como hormônios, toxinas, pigmentos ou antibióticos. Podem ser peptídeos sintases não ribossomal (NRPSs) uma classe de metabólitos secundários peptídicos produzidos por microrganismos como bactérias e fungos (KOLTER \& MORENO, 1992; MARSHALL \& ARENAS, 2003). São sintetizados por sintetases, que, ao contrário dos ribossomos, são independentes da RNA mensageiro. Cada sintetase de peptídeo não ribossomal pode sintetizar um único tipo de peptídeo. Esses compostos são produtos naturais muito diversificados, com uma gama extremamente ampla de atividades biológicas e propriedades farmacológicas. São muitas vezes toxinas, sideróforos e pigmentos (XU et al., 2012). Segundo Muller et al. (2015) a ocorrência de sequências de NRPS foi fortemente dominada pelos membros do filo Protebacteria especialmente do gênero Burkholderia.

Outros peptídeos a serem considerados são as bacteriocinas ou colicinas, definidas como peptídeos ou proteínas biologicamente ativas produzidas por bactérias em condições de estresses, 
e que são capazes de inibir em baixas concentrações até isolados taxonomicamente relacionados (SOUZA \& SOUSA, 2005; CHEIKHYOUSSEF et al., 2008). Podem ser relacionadas como antibióticos por definição, diferenciando dos antibióticos mais clássicos por apresentarem espectro de ação restrito. Podem coferir imunidade á célula hospedeira; sendo sintetizadas ribossomicamente e normalmente não são tóxicas para o hospedeiro (CHEIKHYOUSSEF et al., 2008). As bacteriocinas são moléculas com atividade antibiótica mais abundante e diversificada, abrangendo proteínas de diferentes tamanhos; mecanismo de ação, propriedades de imunidade (RILEY \& WERTZ, 2002).

\subsubsection{Sistema Tol-Pal e sua função}

Para as bactérias gram negativas, o melhor sistema de classificação para as bacteriocinas são os modelos das colicinas. Elas demonstram uma ampla variação de estrutura e mecanimo de ação que incluem a formação de poros, inibição da síntese da parede celuar, atividade DNAse e RNAse (HOLTSMARK et al., 2007 ).

O sistema Tol-Pal compreende um conjunto de proteínas interiplasmáticas associadas à membrana que interligam a membrana interna e externa fornecendo à célula uma estrutura para a divisão celular, transdução de energia e transporte de partículas. Este último é dado pelo consumo da força proton-motriz como força de energia. Os mecanismos envolvidos no transporte de metabólitos secundários são os mesmos envolvidos na liberação de antibióticos relazionados ao mecanismo de resistência (PENFOLD et al., 2012).

O centro do sistema Tol-Pal é encontrada uma proteína TolA que forma interações proteína-proteína com todos os outros membros do sistema e também com proteínas extrínsecas, como colicinas A, E1, E2-E9 e N, e as proteínas de revestimento da família de filamentos e bacteriófagos (WALBURGER et al., 2002).

Os membros desta família de proteínas são a proteína periplasmática TolB encontradas em bactérias Gram-negativas. TolB faz parte do complexo multiproteico Tol-Pal (lipoproteína associada a peptidoglicano), compreendendo cinco proteínas de envelope, TolQ, TolR, TolA, TolB e Pal, que formam dois complexos (GODLEWSKA et al., 2009). As proteínas da membrana interna TolQ, TolR e TolA interagem através dos seus domínios transmembranares (figura 1). O TolB também interage com as proteínas Lpp e OmpA associadas à peptidoglicana da membrana externa. O TolA sofre uma mudança conformacional em resposta a mudanças na força motora de prótons e interage com Pal de uma maneira dependente de energia. O domínio periplasmático C-terminal de TolA também interage com o domínio N-terminal de TolB 
(GODLEWSKA et al., 2009; PENFOLD et al., 2012).

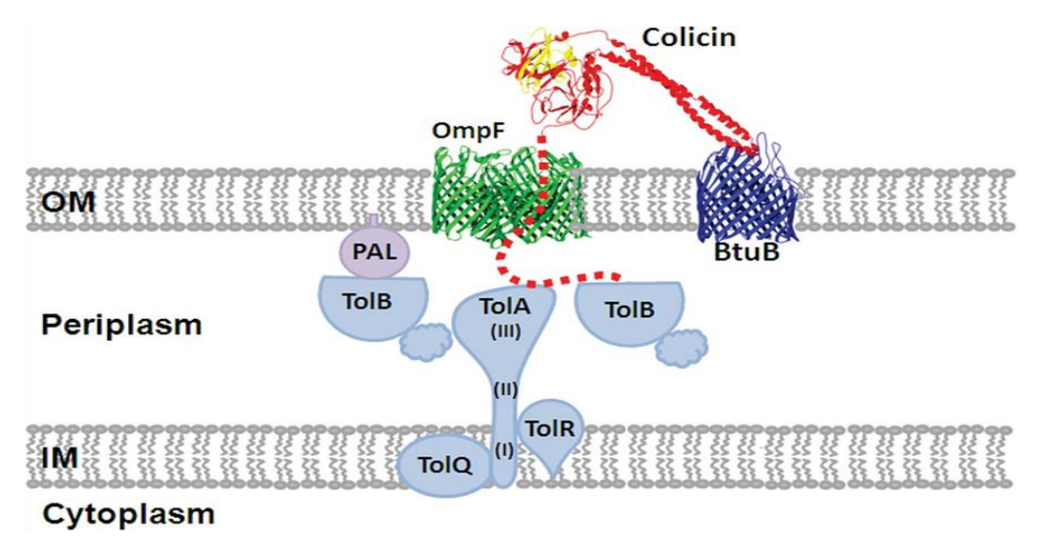

Figura 1: O sistema Tol-Pal. Em de Escherichia coli o TolA consiste em três domínios (I,II,III) que ligam a membrana interna e externa através de interações proteína-proteína com TolR e TolQ na membrana interna e o TolB e Pal no periplasma. ColA liga-se a BtuB através do seu domínio de ligação ao receptor central, e em seguida, recruta OmpF como um translocador através da membrana externa. O domínio N-terminal de ColA insere-se através ou em torno de OmpF e interage com a TolA e TolB (PENFOLD et al., 2012).

Com essas informações é clara a importância do sistema Tol-Pal para a integridade da membrana externa bacteriana. A TolB está envolvida na captação independente de tonB de colicinas do grupo A (colicinas A, E1, E2, E3 e K) e é necessária para que as colicinas atinjam seus respectivos alvos após a ligação inicial à bactéria (PENFOLD et al., 2012). O estudo da sua estrutura sugere que a proteína TolB pode estar envolvida na reciclagem de peptidoglicano ou na sua ligação covalente com lipoproteínas. O sistema Tol-Pal também está implicado na patogênese de algumas bactérias mas o (s) mecanismo(s) não é claro (KIM et al., 2014).

\subsubsection{Glutamato Sintase}

A glutamato sintase (GltS) pode ser conhecida também por: GOGAT ou Glutamina 2oxoglutarato amido-transferase. É constituído por um complexo de flavoproteína ferro-enxofre sintetizada pelos genes $g l t B$ e $g l t D$ e desempenha um papel fundamental nas vias de assimilação de amônia encontradas em bactérias e plantas (LEA \& MIFLIN, 2018). A GltS catalisa uma interessante conversão na qual o nitrogênio da cadeia lateral da glutamina é transferido para $\alpha$ cetoglutarato para formar duas moléculas de glutamato após a aquisição de dois elétrons de um redutor adequado (RICHARDS et al., 2010). A amônia é a primeira opção entre as fontes de nitrogênio incorporadas pelos aminoácidos glutamina e glutamato os quais são os principais doadores de átomos de nitrogênio para outros compostos nitrogenados e seus derivados 
(RICHARDS et al., 2010). Informações detalhadas sobre o mecanismo cinético e químico dessa enzima complexa foram obtidas principalmente por meio de estudos da enzima da bactéria fixadora de nitrogênio Azospirillum brasilense (RICHARDS et al., 2010). Esse gene GltS procariótico é um heterodímero no qual ambos os sítios da glutamina e sua sintase estão localizados na subunidade $\alpha$ da enzima juntamente com um cofator FMN e um aglomerado [3Fe4S], que norteiam o elétron de transferência. Em planta o GltS, está evolutivamente relacionada à forma da enzima presente nas cianobactérias, uma cadeia polipeptídica única que contém um cofator FMN e um cluster [3Fe-4S] (MANDER \& LIU, 2010). Para essa enzima, no entanto, a fonte de poder redutor é a ferredoxina, que transfere elétrons para o cofator FMN formando um complexo transiente com a subunidade $\alpha$.

\subsection{Mutantes obtidos a partir do transposson Tn5}

A mutagênese por transposon, ou seja mutagênese por transposição, é um processo biológico que permite que sequencias de DNA sejam transferidas para o cromossomo de um organismo hospedeiro, interrompendo ou modificando a função de um gene existente no cromossomo e causando mutação (GHATAK, 2011). A mutagênese por transposon é muito mais efetiva que a mutagênese química, com uma maior frequência de mutação e menor chance de matar o organismo. Outras vantagens incluem ser capaz de induzir mutações de acerto único, ser capaz de incorporar marcadores selecionáveis na construção de linhagens e ser capaz de recuperar genes após mutagênese (SEIFERT et al., 1986). As desvantagens incluem a baixa frequência de transposição em sistemas vivos e a imprecisão da maioria dos sistemas de transposição.

No caso de bactérias, a mutagênese por transposição é geralmente realizada por meio de um plasmídeo do qual um transposon é extraído e inserido no cromossomo hospedeiro. Isso geralmente requer que um conjunto de enzimas, incluindo transposase, seja traduzido. A transposase pode ser expressa em um plasmídeo separado, ou no plasmídeo contendo o gene a ser integrado. O sistema transposon Tn5 é um sistema modelo para o estudo da transposição e para a aplicação da mutagênese do transposon. Tn5 é um transposon caracterizado pela heterogeneidade e versatilidade, onde os genes (o sistema original contendo genes de resistência a antibióticos) são flanqueados por duas sequências de inserção quase idênticas, denominadas IS50R e IS50L correspondentes aos lados direito e esquerdo do transposon respectivamente (GORYSHIN \& REZNIKOFF, 1998). Estas sequências são ambas flanqueadas por elementos de 19 pares de bases nas extremidades interna e externa do transposon. A mutação dessas regiões 
resulta na incapacidade de os genes da transposase se ligarem às sequências. Logo a utilização desta ferramenta se tornou muito útil para o estudo de fenômenos biológicos favorecendo a caracterização de genes, devido sua inserção aleatória e a facilidade em selecionar mutantes devido ao gene resistente a canamicina.

A biblioteca de mutantes utilizados neste trabalho foi construída através da inserção aleatória do transposon Tn5 no genoma da bactéria Burkbolderia seminalis TC3.4.2R3 gerando assim os mutantes. 


\section{JUSTIFICATIVA}

O estudo de genes em bactérias endofíticas responsáveis pelo controle de doenças é relativamente novo e pode ser uma importante ferramenta para o conhecimento de possíveis novas moléculas com potencial biotecnológico, e um aprofundamento sobre suas propriedades, contribuindo para o desenvolvimento de produtos aplicáveis na agricultura e em áreas afins. Assim, a crescente procura por novos compostos bioativos contra fitopatógenos derivados de microrganismos demonstra a importância de estudos em nível gênico destes compostos. O presente trabalho foi idealizado mediante uma série de estudos preliminares que demonstraram o potencial para controle biológico e a busca de novos genes a partir de bactérias pertencentes ao gênero Burkholderia, mais precisamente a linhagem B. seminalis TC3.4.2R3. Dentre patógenos que merecem atenção, destacamos o gênero Fusarium, causador de doenças nas mais diversas culturas com destaque para cana-de-ácucar, milho, ervilha, dentre outros. Dessa forma, este trabalho visou a busca de genes de B. seminalis linhagem TC3.4.2R3, relacionados ao controle biológico da fusariose e a especificidade desses compostos mediante diferentes espécies de Fusarium. 


\section{OBJETIVOS:}

\subsection{Objetivo geral}

Identificar genes de Burkholderia seminalis linhagem (TC3.4.2R3) relacionados à inibição de crescimento de fitopatógenos Fusarium spp. e caracterizar os mesmos visando o melhor entendimento dos mecanismos envolvidos no controle da fusariose.

\subsubsection{Objetivos específicos:}

i) caracterizar mutantes B. seminalis TC3.4.2R3 provenientes da biblioteca obtida por $\operatorname{Tn} 5$ quanto a perda da capacidade de inibir o crescimento de F. verticilioides;

ii) caracteriação dos mutantes selecionados quanto a termoestabilidade dos metabólitos produzidos no controle de F. verticilioides e livre de células;

iii) especificidade dos mutantes selecionados no controle de Fusarium spp;

iv) identificar dos genes nocauteados nos mutantes selecionados de B. seminalis TC3.4.2R3 relacionados ao controle de Fusarium spp;

v) análise in silico do genoma e genes nocauteados dos mutantes defectivos para controle da fusariose, afim de compreender o mecanismo de biosíntese e biocontrole de moléculas biotivas produzidas pela linhagem B. seminalis TC3.4.2R3 por meio da biblioteca de mutantes. 


\section{MATERIAL E MÉTODOS}

\subsection{Material biológico}

No presente estudo foi utilizada a linhagem selvagem TC3.4.2R3 de B. seminalis e seus 1788 mutantes previamente obtidos por Mano (2011). A linhagem TC3.4.2R3 e seus mutantes foram gentilmente cedidas pelo Prof. Dr. Welington Luiz de Araújo do Laboratório de Biologia Molecular e Ecologia Microbiana (Departamento de Microbiologia, ICB/USP). A linhagem selvagem TC3.4.2R3 foi isolada endofiticamente de raiz de cana-de-açúcar por Marcon (2007) e Rossetto (2008). Mendes et al., (2007) e Luvizzoto et al., (2010) realizaram as primeiras caracterizações dessa linhagem em relação a produção de enzimas comprovando seu potencial para fixação de nitrogênio, produção de AIA, sideróforos e solubilização de fosfato. Luvizotto et al., (2010), também verificou seu o potencial de biocontrole contra diferentes patógenos de canade-açúcar.

Mano (2011), construiu uma biblioteca de mutantes randômicos a partir da linhagem $B$. seminalis TC3.4.2R3, utilizando o transposon Tn5, por meio do transposoma EZ-Tn5 $<$ R6Kyori/KAN-2>, que apresenta um complexo estável formado pela enzima trasnposase, tendo o gene de resistência a canamicina como marca de seleção (Epicentre, Biotechnologies, Madison, Wisconsin, USA).

Para a manutenção da linhagem selvagem TC3.4.2R3, bem como seus mutantes, foi utilizado o meio LB (10grs. Triptona, 5grs. extrato de levedura, 10grs. $\mathrm{NaCl}$, 18grs. ágar), sendo os mutantes crescidos em meio suplementado com canamicina $\left(200 \mu \mathrm{g} \cdot \mathrm{mL}^{-1}\right)$. As linhagens foram crescidas em meio LB e posteriormente adicionado glicerol para uma concentração final de $60 \%$ e estocadas à $-80^{\circ} \mathrm{C}$. Todos os experimentos foram rotineiramente iniciados com culturas frescas crescidas em meio LB, sendo acrescentado canamicina ao meio de cultura para os mutantes e crescido a $28^{\circ} \mathrm{C}$.

F. verticilioides FV-01 CTC, patógeno de cana-de-açúcar gentilmente cedido pela Doutora Sabrina Moutinho Chábregas do Centro de Tecnologia Canavieira (CTC), Piracicaba-SP. Além do fitopatóegno F. verticilioides FV-01-CTC, causador do Pokeka Boing em cana-de-açúcar, foram utilizados outros fitopatógenos Fusarium spp. (Tabela 1). F. oxysporum isolados: R2 238 e R5 são fitopatógenos de ervilha. F. verticilioides T4 Ø, é um isolado patogênico de milho e foi gentilmente cedido por Dr. Cynthia M. Ocamb, Universidade do Estado de Oregon (Oregon States University- OSU).

Os fitopatógenos pertencem a coleção de micro-organismo do laboratório de Genética de Micro-organismo “Prof. João Lúcio de Azevedo”, Departamento de Genética, ESALQ/USP. 
Os isolados fúngicos foram rotineiramente crescidos em meio de batata dextrose e ágar (BDA) (Difco) e estocados à temperatura ambiente, em discos de BDA imersos em água destilada autoclavada.

Tabela 1: Linhagens fitopatogênicas do gênero Fusarium utilizadas nos ensaios de antagonismo

\begin{tabular}{llll}
\hline Isolado & Espécie & Hospedeiro & Referência \\
\hline FV-01 CTC & F. verticilioides & Cana-de-açúcar & Quecine, 2010 \\
T4 $\varnothing$ & F. verticilioides & Milho & Quecine et al. 2016 \\
R2 238 & F. oxysporum & Ervilha & Quecine et al. 2016 \\
R5 & F. oxysporum & Ervilha & Quecine et al. 2016 \\
\hline
\end{tabular}

\subsection{Atividade antimicrobiana in vitro da linhagem TC3.4.2R3 contra Fusarium spp.}

A capacidade da linhagem selvagem TC3.4.2R5 de inibir o crescimento dos fitopatógenos de Fusarium spp. (Tabela 1) foi avaliada por meio do método de pareamento de culturas. Para tanto, em uma das extreminadades placa de Petri contendo meio de cultura BDA foi estriada a linhagem TC3.4.2R3, no centro da placa foi inoculado um disco de $2 \mathrm{~cm}$ de diâmetro do fungo (Figura 2). Após a inoculação, as culturas foram incubadas à $28^{\circ} \mathrm{C}$ por 7 dias. O tratamento controle consistiu do fitopatógeno inoculado no centro da placa de Petri, na ausência da linhagem TC3.4.2R3 e incubados sob as mesmas condições. O ensaio foi realizado em triplicatas biológicas para cada tratamento.

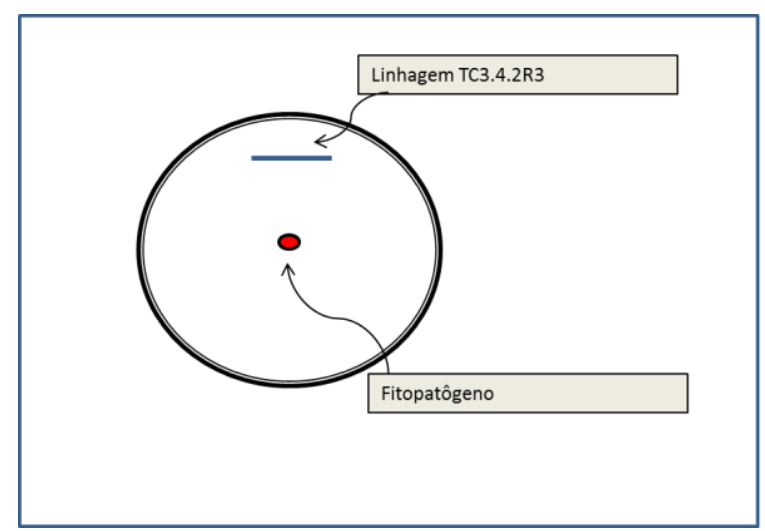

Figura 2: Esquema do ensaio de inibição do crescimento de Fusarium spp. pela linhagem selvagem B. seminalis TC3.4.2R3. 


\subsection{Seleção de mutantes defectivos na inibição de $F$. verticilioides FV-01 CTC}

A seleção de mutantes defectivos no controle da fusariose foi realizada utilizando o fitopatógeno F. verticilioides FV-01-CTC, que apresentou maior inibição de crescimento quando pareado com a linhagem selvagem TC3.4.2R3 (item 5.2). O ensaio foi realizado por meio de pareamento in vitro em meio de cultura $\mathrm{BDA}$, onde em dois quadrantes da placa de Petri foram inoculados por estriamento mutantes randômicos a partir da linhagem B. seminalis TC3.4.2R3, utilizando o tansposon Tn5 (NEVES, 2011). No terceiro quadrante foi estriada a linhagem selvagem TC3.4.2R3 como controle positivo. No centro da placa foi inoculado um disco de $2 \mathrm{~cm}$ de diâmetro do fitopatógeno F. verticilioides FV-01-CTC (Figura 3). Após a inoculação, as placas foram incubadas à $28^{\circ} \mathrm{C}$ por 7 dias. Os ensaios foram realizados em triplicata e avaliados qualitativamente.

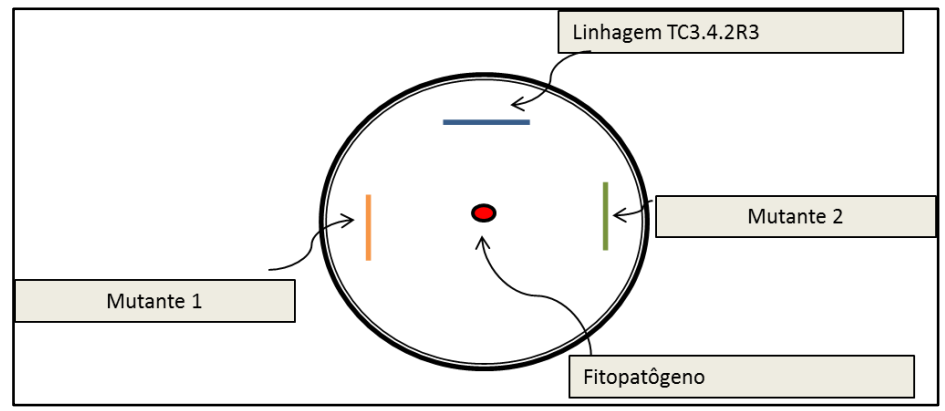

Figura 3: Esquema da seleção de mutantes defectivos para inibição do crescimento de Fusarium verticilioides FV-01CTC.

Os mutantes selecionados no teste qualitativo como defectivos na inibição do crescimento de F. verticilioides FV-01-CTC foram então utilizados em ensaios semi-quantitativos de inibição do mesmo fitopatógeno. Para tanto, $10 \mu \mathrm{L}$ de solução bacteriana $\left(10^{8} \mathrm{UFC} . \mathrm{mL}^{-1}\right)$ da linhagem TC3.4.2R3 foram inoculadas em uma extremidade da placa de Petri contendo meio de cultura BDA, em outra extremidade foi adicionado o mutante defectivo selecionado e no centro da placa foi colocado disco de $2 \mathrm{~cm}$ de diâmetro do fungo.

O índice de inibição foi calculado de acordo com a fórmula: raio de crescimento das laterais do fungo que não estavam expostas a ação bacteriana (y2) foram consideradas $100 \%$. A partir desse valor foi calculada a redução do crescimento fúngico nas laterais expostos a ação bacteriana (y1) de acordo com a fórmula: (y1/y2)*100 (QUECINE et al. 2016) (Figura 4). 


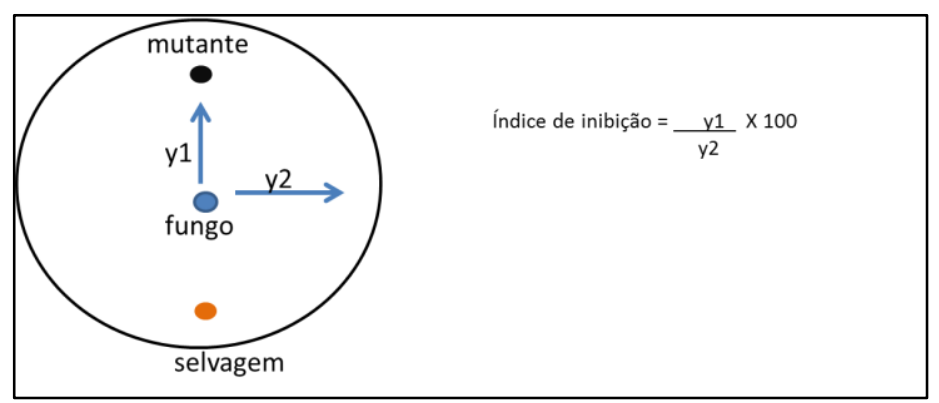

Figura 4: Esquema proposto para verificação da inibição do crescimento de F. verticilioides FV-01-CTC pela linhagem selvagem TC3.4.2R3 e seus mutantes (esquerda). Fórmula utilizada para a avaliação do índice de inibição dos mutantes (direita), adaptado de Quecine et al. (2016).

Cada mutante foi avaliado em quintuplicata. Os dados foram submetidos à analise de variância e a comparação de médias feitas pelo teste de Tukey a 5\% de probabilidade.

Os mutantes defectivos na capacidade de inibir o F. verticilioides FV-01-CTC foram avaliados quanto a termoestabilidade dos possíveis compostos produzidos e a presença dos mesmo na membrana celular.

\subsection{Avaliação da produção de compostos antifúngicos termoestáveis pela linhagem} TC3.4.2R3 e seus mutantes defectivos no controle de $\boldsymbol{F}$. verticilioides FV-01-CTC

A termoestabilidade dos possíveis compostos antifúngicos produzidos pela linhagem TC3.4.2R3 e os mutantes defectivos na inibição de crescimento de F. verticilioides FV-01-CTC foi realizado de acordo com o método descrito por Soria et al., (2015). A linhagem TC3.4.2R3 (selvagem e mutantes) foram transferidas, separadamente, por meio de uma alça de repicagem para frascos Erlenmeyer de $250 \mathrm{~mL}$ contendo $100 \mathrm{~mL}$ de BD. Em seguida, as culturas foram incubadas em agitador a $28^{\circ} \mathrm{C}$ a $180 \mathrm{rpm}$ durante 5 dias. Transcorrido este período, uma alíquota de $10 \mathrm{~mL}$ foi retirada de cada frasco e transferida para novos frascos Erlenmeyer de $250 \mathrm{~mL}$ contendo $90 \mathrm{~mL}$ de BDA. Os meios de cultura foram autoclavados por 20 minutos, a $120^{\circ} \mathrm{C}$ e a 1 atm de pressão e vertidos $20 \mathrm{~mL}$ em 5 placas de Petri. Após a solidificação, um disco de $5 \mathrm{~mm}$ de diâmetro, obtido de colônias ativas de F. verticilioides FV-01-CTC foi transferido para o centro de cada placa de Petri contendo no meio de cultura bactérias (mortas) e seus metabólitos produzido.

\subsection{Avaliação da produção de metabólitos livres de células pela linhagem} TC3.4.2R3 selvagem e seus mutantes defectivos no controle de $F$. verticilioides FV-01-CTC

A linhagem TC3.4.2R3 (selvagem e mutantes) foram transferidas, através de uma alça de repicagem para frascos Erlenmeyer de $250 \mathrm{~mL}$ contendo $100 \mathrm{~mL}$ de BD. Em seguida, as culturas 
foram incubadas em agitador $28^{\circ} \mathrm{C}$ a $180 \mathrm{rpm}$ durante 5 dias. Após esse período, a cultura foi centrifugada e filtrada em membrana millipore $(0,22 \mu \mathrm{m})$ a fim de retirar células ou partes solutas, e uma alíquota de $10 \mathrm{~mL}$ foi transferida para frascos de Erlenmeyer de $250 \mathrm{~mL}$ contendo $90 \mathrm{~mL}$ de meio BDA fundente. Depois de vertidos e solidificados os meios em placas de Petri, um disco de $5 \mathrm{~mm}$ de diâmetro obtido de colônias ativas de F. verticilioides FV-01-CTC foi transferido para o centro das mesmas. O controle foi representado pelo fitopatógeno, em placas contendo apenas o meio de cultura BDA.

\subsection{Avaliação da especificidade da atividade antagônica de mutantes defectivos} no controle de Fusarium spp.

A capacidade dos mutantes defectivos no controle de FV-01-CTC em inibir o crescimento dos fitopatógenos de Fusarium spp. (Tabela 1) foi avaliado por meio do método de pareamento de culturas. Para tanto, em uma das extreminadades da placa de Petri contendo meio de cultura BDA foi estriada a linhagem TC3.4.2R3 no centro da placa foi inoculado um disco de $2 \mathrm{~cm}$ de diâmetro do fungo. Após a inoculação, as culturas foram incubadas a $28^{\circ} \mathrm{C}$ por 7 dias. $\mathrm{O}$ tratamento controle consistiu do fitopatógeno inoculado no centro da placa de Petri, na ausência da linhagem TC3.4.2R3 incubados sob as mesmas condições. A análise do resultado foi verificada pelo crescimento ou não da colônia.

5.7 Caracterização, clonagem e sequenciamento das regiões que flanqueam o transposon em mutantes defectivos para inibição do crescimento do F. verticilioides FV-01CTC

\subsubsection{Extração do DNA bacteriano}

O DNA genômico da linhagem TC3.4.2R3 e de seus mutantes defectivos para inibição do crescimento do fitopatógeno F. verticilioides FV-01-CTC foram extraídos para análises moleculares. As linhagens foram crescidas em $5 \mathrm{~mL}$ de meio $\mathrm{LB}$ a $28^{\circ} \mathrm{C}$ por 18 horas. Após esse período cada linhagem foi centrifugada por 5 minutos a $12.000 \mathrm{~g}$ e o sedimentado (pellet) foi ressuspendido em $500 \mu \mathrm{L}$ de TE $(10 \mathrm{mM}$ de Tris-HCl), $80 \mu \mathrm{L}$ de SDS 10\% e 0,5g de pó de sílica e levado ao vórtex por 1 minutos. Em seguida incubado no banho-seco por 10 minutos a $80^{\circ} \mathrm{C}$. A suspensão foi vortexada por 1 minuto e adicionado $500 \mu \mathrm{L}$ de fenol saturado, agitado levemente e centrifugado por 7 minutos a $12.000 \mathrm{~g}$. O sobrenadante foi transferido para um novo microtubo 
com o auxílio de uma pipeta e o DNA foi purificado pelo método fenol-clorofórmio de acordo com a metodologia estabelecida por Sambrook \& Russell (2001).

O sobrenadante foi transferido para novos microtubos, e adicionados $4 \mu \mathrm{L}$ de $\mathrm{NaCl} 5 \mathrm{M}$ e $400 \mu \mathrm{L}$ de isopropanol para a precipitação do DNA, incubado em gelo por 5 minutos e em seguida centrifugada por 7 minutos, descartando o sobrenadante. O precipitado foi lavado com etanol 70\%, centrifugado por mais 7 minutos e o sobrenadante descartado. Foi adicionado ao pellet $500 \mu \mathrm{L}$ de etanol 100\% e centrifugado por mais 3 minutos. Em seguida, o sobrenadante foi descartado e o pellet seco em banho seco por 30 minuto a $60^{\circ} \mathrm{C}$. Após a secagem, o DNA foi ressuspendido em $70 \mu \mathrm{L}$ de água deionizada esterilizada. A concentração e a integridade dos DNA's extraídos foram verificadas em gel de agarose 1,0\% utilizando como padrão de comparação o marcador Lambda ( $\lambda$ ), nas concentrações de 25, 50, 75 e 100 ng. $\mu \mathrm{L}^{-1}$.

\subsubsection{Comprovação da presença do transposon Tn5 nos mutantes selecionados} por PCR

A presença do transposon Tn5 no DNA dos mutantes defectivos na inibição do crescimento de FV-01-CTC foi confirmada através da utilização de um par de oligonucleotídeos que amplificam as regiões parciais deste transposon: Tn5F (5' GGACGCGATGGATATGTTCT- 3’) e Tn5R (5' -GATGGTCGGAAGAGGCATAA- 3') (ARAÚJO et al., 2016). Para a reação de PCR foi utilizado 100 ng de DNA, 10x PCR buffer, 0,5mM dNTPs, $0,2 \mu \mathrm{M}$ de cada primer e 1,0U Taq polimerase. As reações foram conduzidas em termociclador programado para: desnaturação inicial de $95^{\circ} \mathrm{C}$ por 5 minutos, seguido de 35 ciclos de amplificação a $94^{\circ} \mathrm{C}$ por 30 segundos, $55^{\circ} \mathrm{C}$ por 30 segundos, $72{ }^{\circ} \mathrm{C}$ por 1 minuto, e uma extensão final a $72{ }^{\circ} \mathrm{C}$ por 10 minutos. O produto de PCR foi avaliado em gel de agarose $1 \%$ para observação de um fragmento esperado de 399 pb, respectivamente, utilizando o marcador $1 \mathrm{~Kb}$ e 100pb (Fermentas Life Sciences, Brasil).

\subsubsection{Clonagem dos genes nocauteados por Tn5}

\subsubsection{Obtenção de células competentes}

Células eletrocompetentes de E. coli DH5 $\alpha$-pir foram obtidas a partir da inoculação de uma colônia bacteriana em $5 \mathrm{~mL}$ d meio SOC (10g Triptona; $5 \mathrm{~g}$ extrato de levedura; $0,05 \mathrm{~g} \mathrm{NaCl}$; pH 7,0), posteriormente incubado sob agitação de $200 \mathrm{rpm}$, a $28^{\circ}$ por $18 \mathrm{~h}$. Após o crescimento, a 
cultura foi transferida para um frasco contendo $250 \mathrm{~mL}$ de meio SOB (2g Triptona; $5 \%$ extrato de levedura; $10 \mathrm{mM} \mathrm{NaCl}$ ), a $28^{\circ} \mathrm{C}$ sob agitação de $200 \mathrm{rpm}$, até atingir uma densidade ótica entre 0,4 a 0,6 ( $\left(\mathrm{OD}_{600 \mathrm{~nm}}\right)$ medida em espectrofotômetro (Ultrospec 3000 Amersham Pharmacia Biotech). Após atingir a OD desejada, a cultura foi centrifugada a velocidade de 5000g por 10 minutos a $4^{\circ} \mathrm{C}$. O sobrenadante foi descartado e o precipitado ressuspendido em glicerol $10 \%$ e centrifugado novamente. O sobrenadante foi descartado e o precipitado foi ressuspendido em glicerol 10\% seguido de diluição para atingir uma $\mathrm{OD}$ de $0,100\left(\mathrm{OD}_{600}\right)$. Alíquotas de $100 \mu \mathrm{L}$ foram estocadas a $-80^{\circ} \mathrm{C}$.

\subsubsection{Preparo do DNA genômico dos mutantes da linhagem TC3.4.2R3}

Para a realização da clonagem das regiões flanqueadoras do transposon em E. coli DH5 $\alpha$-pir, foram utilizados 600ng do DNA de cada mutante, sendo clivados com $5 \mathrm{U}$ da enzima de restrição EcoRI (NEB) e incubado $37^{\circ} \mathrm{C}$ por 4 horas. Posteriormente o produto clivado foi precipitado com 0,1 volume de acetato de amônio a 7,8 M e 2,5x volume de etanol absoluto, e em seguida incubado a $-20{ }^{\circ} \mathrm{C}$ overnight. Após este período, o DNA clivado com EcoRI e precipitado em acetato de amônio/etanol, foi centrifugado a $12.000 \mathrm{rpm}$ por 40 minutos a $4^{\circ} \mathrm{C}$. Em seguida, o sobrenadante foi descartado e adicionado $700 \mu \mathrm{L}$ de etanol $70 \%$ ao DNA precipitado. As amostras foram novamente centrifugadas por 10 minutos $\left(12.000 \mathrm{rpm} \mathrm{a} 4^{\circ} \mathrm{C}\right)$ e o sobrenadante obtido foi descartado e o precipitado seco a $37^{\circ} \mathrm{C}$ e ressuspendido em $7,0 \mu \mathrm{L}$ de água deionizada estéril e incubado em banho seco a $65^{\circ} \mathrm{C}$ por 30 minutos. Os fragmentos obtidos da digestão foram circularizados com a enzima T4 DNA ligase (Invitrogen) por 18 horas a $4^{\circ} \mathrm{C}$. Após a ligação, os fragmentos foram introduzidos em células de E. coli (DH5 $\alpha$-pir)

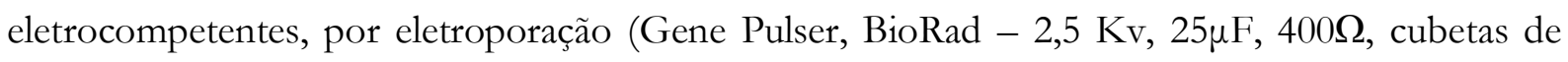
$0,2 \mathrm{~cm})$

Após a eletroporação as células foram imediatamente transferidas para microtubos com meio LB a um volume final de $1 \mathrm{~mL}$, e incubadas a $37^{\circ}$ durante 60 minutos, sob agitação. Cem microlitros (sem diluição e concentrado de $800 \mu \mathrm{L}$ após centrifugação) da suspensão foram semeados em meio LB sólido contendo $200 \mu \mathrm{g} / \mathrm{mL}$ de canamicina. As placas foram incubadas a $37^{\circ}$ por até 24 horas, e as colônias crescidas foram armazenadas em meio LB suplementado com canamicina $200 \mu \mathrm{g} / \mathrm{mL}$, contendo $60 \%$ de glicerol e estocada a $-80^{\circ} \mathrm{C}$.

\subsubsection{Extração do DNA plasmidial de clones Tn5 de E. coli DH5 $\alpha$-pir}


O DNA plasmidial dos clones Tn5 E. coli DH5 $\alpha$-pir foi extraído utilizando o Kit PureLink Quick Plasmid Minprep (Invitrogen). Dois clones representantes de cada isolado mutante transformado foram crescidos em $100 \mathrm{~mL}$ de meio LB suplementado com canimicina $200 \mu \mathrm{g} / \mathrm{mL}$, crescidos sob agitação a $170 \mathrm{rpm}$, durante 24 horas a $37^{\circ} \mathrm{C}$. Após o crescimento, a cultura foi centrifugada e todo sobrenadante descartado, e a miniprep foi conduzida conforme o protocolo do fabricante. O DNA plasmidial extraído foi ressupendido em $150 \mu \mathrm{L}$ de água deionizada autoclavada. A concentração do DNA plasmidial foi quantificada através do Nanodrop, e a integridade do DNA plasmidial, seu tamanho, e a ocorrência ou não por DNA genômico, foram verificadas em gel de agarose 1,0\%. Para isso, cerca de 500 ng do DNA extraído foram tratados com a enzima de restrição EcoR1, incubados entre 1 a 3 horas a $37^{\circ} \mathrm{C}$, para linearização do plasmídeo.

\subsubsection{Sequenciamento e análise das regiões flanqueadoras do transposon}

Para a identificação das sequências de DNA dos genes interrompidos pelo transposon EZ-Tn5 <R6Kygori/KAN-2>KAN-2-Tnp, o DNA circularizado contendo o transposon, extraído de células de E. coli DH5 $\alpha$-pir foi submetido ao sequenciamento, sendo a reação realizada a jusante e a montante utilizando os primers que anelam nas extremidades do transposon KAN-2 FP-1 (5'-ACCTACAACAAAGCTCTCATCAACC-3') e R6KAN-2 RP-1 (5'CTACCCTGTGGAACACCTACATC-3'). Foram selecionados dois clones representantes de cada mutante selecionado e os mesmos foram sequenciados em duplicata a jusante e a montante totalizando 16 sequências. As sequências obtidas foram visualizadas e editadas utilizando o software MEGA 5 (TAMURA et al., 2011). Após as sequências foram analisadas com o auxílio da ferramenta BLAST, o Blastn (análise de nucleotídeos) e Blastx (análise de proteínas) contra a base de dados do GenBank.

\subsubsection{Análises in silico de genes candidatos ao controle da fusariose}

Para as análises in silico dos genes encontrados nos mutantes defectivos para fusariose, foi utilizado o genoma parcial (draft) da linhagem TC3.4.2R3 depositado no NCBI cedido pelo Dr. Welington Luiz de Araújo (acesso LAEU01000000). Com a ferramenta Blastx foi realizada a verificação de domínios putativos de proteínas hipotéticas e confirmado o resultado com outras bases de dados. 
Em paralelo, foi realizada a busca de clusters para a produção de metabólitos secundários presentes no genoma de TC3.4.2R3 por meio do programa Antibiotics \& Secondary Metabolite Analysis Shell (antiSMASH, http://antismash.secondarymetabolites.org/) (MEDEMA, 2011).

\subsection{Caracterização dos mutantes defectivos para síntese de glutamato e proteína TolB}

Selecionamos os mutantes M15 (defectivo para a síntese de glutamato) e M17 (defectivo para a proteína TolB) para caracterizar as possíveis alterações no comportamento de B. seminalis por meio de alterações em seu crescimento.

Em relação ao gene gluatamao sintase também foram avaliados os mutantes MR3 e 2gg, ambos gentilmente cedidos pelo Dr. Welington Luiz de Araújo. O mutante MR3, que tem marca de seleção cloranfenicol $50 \mathrm{ug} / \mathrm{ml}$, é um mutante defectivo para síntese de glutamato sintase por troca alélica. O mutante $2 \mathrm{gg}$ é o mutante MR3 com a reinserção do gene glutamato sintase contendo dupla resistência: cloranfenicol $(50 \mathrm{ug} / \mathrm{ml})$ e canamicina $(200 \mathrm{ug} / \mathrm{ml})$. Para manutenção

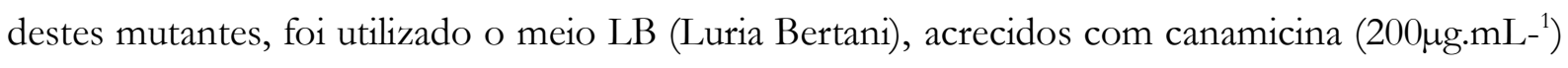
para os mutantes M15 e M17; para o mutante MR3 meio LB acrescido com cloranfenicol (50 $\mathrm{ug} / \mathrm{ml}$ ); e para o mutante $2 \mathrm{gg}$ meio LB acrescido com cloranfenicol (50 ug/ml) mais canamicina (200 ug/ml). As linhagens foram crescidas em meio LB líquido e posteriormente adicionado glicerol $60 \%$ e estocadas à $-80^{\circ} \mathrm{C}$.

\subsubsection{Característica fisiológica relacionada à curva de crescimento dos mutantes}

Foi obtida a curva de crescimento da linhagem TC3.4.2R3 selvagem, os mutante: M15, M17, $2 \mathrm{gg}$ e MR3. As linhagens foram crescidas em placas com meio LB e acrecidas de antibiótico apropriado, por 3 dias à $28^{\circ} \mathrm{C}$. Uma unidade formadora de colônia de cada linhagem foi inoculada em tubos contendo $10 \mathrm{~mL}$ de meio LB líquido. O pré-inóculo foi mantido a $28^{\circ} \mathrm{C}, 180 \mathrm{rpm}$ durante 24 horas. Após esse período, foi retirada uma alíquota de $1 \mathrm{~mL}$ para verificação da densidade ótica em espectrofotômetro (Ultrospec 3000 Amersham Pharmacia Biotech) a OD $_{600 \mathrm{~nm}}$ e realizado ajustes de concentração bacteriana e volume, afim de padronizar a concentração inicial de todas as amostras em $\mathrm{OD}_{600 \mathrm{~nm}}=0,02 \mathrm{em}$ erlenmeyer contendo $50 \mathrm{~mL}$ de meio $\mathrm{LB}$ e incubadas a $28^{\circ} \mathrm{C}, 120 \mathrm{rpm}$. A cada duas horas, $1 \mathrm{~mL}$ da cultura era retirado para a realização das leituras da densidade ótica em um comprimento de onda à $600 \mathrm{~nm}$. O ensaio foi realizado em triplicata para cada tratamento. 


\subsubsection{Atividade de antagonismo in vitro dos mutantes com silenciamento para glutamato sintase e proteína TolB contra F. verticilioides FV-01-CTC}

Os mutantes caracterizados para a perda da atividade da glutamato sintase (M15, MR3) e da proteína TolB (M17) foram submetidos a testes semi-quantitativos de antagonismo por pareamento contra o crescimento de F. verticilioides FV-01-CTC. O mutante 2gg e a linhagem selvagem TC3.4.2R5 como controle positivo. Para tanto, $10 \mu \mathrm{L}$ de solução bacteriana $\left(10^{8}\right.$ UFC.

$\mathrm{mL}^{-1}$ ) da linhagem TC3.4.2R5 selvagem foi inoculada em uma extremidade da placa de Petri contendo meio de cultura BDA, e em outra extremidade foi adicionado o mutante defectivo selecionado e no centro da placa foi inoculado disco de $2 \mathrm{~cm}$ de diâmetro do fungo. O índice de inibição foi calculado de acordo com a fórmula: $100 \%$ - 100\%* (b/a). Onde 100 é valor de crescimento total em placa e $a$ e $b$ são os quadrantes da placa. O ensaio foi realizado em quadriplicata para cada tratamento.

\subsubsection{Caracterização molecular através de Southern Blot}

Para verificar o número de inserções do plasmídeo Tn5 no genoma da linhagem TC3.4.2R3:Tn5, foi utilizada a técnica de Sothern blot.

\subsubsection{Extração de DNA bacteriano}

A linhagem TC3.4.2R3 selvagem, bem como os mutantes defectivos selecionados (M15 e M17) tiveram seus DNA's extraídos de acordo com o protocolo descrito no item 2.5.1.

\subsubsection{Restrição do DNA genômico e transferência para a membrana de náilon}

Os DNA's extraídos foram clivados com a enzima de restrição EcoR1 (Invitrogen). As reações de restrição em um volume total de $250 \mu \mathrm{L}$, contendo 7,5 $\mu \mathrm{g}$ de DNA bacteriano ou 500ng do plasmídeo Tn5, $25 \mu \mathrm{L}$ de tampão React 3 10X e 40U da enzima EcoR1, foram incubadas a $37^{\circ} \mathrm{C}$ durante 12 horas. Para concentrar foi realizada uma precipitação adicionando $25 \mu \mathrm{L}$ de acetato de amônio 7,8M e $625 \mu \mathrm{L}$ de álcool 70\%. As amostras foram centrifugadas por mais 10 minutos $\left(10.000 \mathrm{xg}, 4^{\circ} \mathrm{C}\right)$. O sobrenadante foi novamente descartado e o precipitado seco a $37^{\circ} \mathrm{C}$. Após a secagem, o DNA hidrolisado foi resuspenso em $32 \mu \mathrm{L}$ de TE e $8 \mu \mathrm{L}$ de sacarose 
40\%. Os $40 \mu \mathrm{L}$ de DNA foram aplicados em gel dea agarose 1\%. Como marcador de peso molecular, $40 \mu \mathrm{L}$ do DNA Ladder $1 \mathrm{~Kb}\left(0,2 \mu \mathrm{g} . \mu \mathrm{L}^{-1}\right)$ (Fermentas), foi utilizado. A eletroforese, foi realizada a 1 volt.cm ${ }^{-1}$. O gel foi posteriormente corado com brometo de etídio $\left(1,0 \mathrm{mg} \cdot \mathrm{mL}^{-1}\right)$ e fotodocumentado.

O gel de agarose foi então submetido à depurinização por incubação em $500 \mathrm{~mL}$ de solução $\mathrm{HCl}$ 0,25M por 10 minutos. Após este período, o gel foi lavado com água destilada e transferido para $500 \mathrm{~mL}$ de solução desnaturante $(\mathrm{NaOH} 0,5 \mathrm{M} ; \mathrm{NaCl} 1,5 \mathrm{M})$ por 30 minutos. $\mathrm{O}$ gel foi lavado novamente com água destilada, e em seguida neutralizado por incubação por 15 minutos em $250 \mathrm{~mL}$ de solução neutralizadora (Tris-HCl 0,5 M; NaCl 1,5 M; EDTA 0,001 M; $\mathrm{pH} 7,2)$, com agitação branda a temperatura ambiente. Este procedimento foi repetido mais uma vez. Por capilaridade, o DNA contido no gel foi transferido para a membrana de nálion (HYBOND-N+ - AMERSHAMP), sendo utilizada a solução de transferência SSC 20X ( NaCl $3 \mathrm{M}$; citrato de sódio $0,3 \mathrm{M} ; \mathrm{pH} 7,0)$. O DNA foi fixado à membrana por aquecimento $\left(80^{\circ} \mathrm{C}\right.$ por 2 horas) e então armazenada à temperatura ambiente.

\subsubsection{Preparo da sonda e hibridização molecular}

Para a hibridização foi utilizado como sonda um fragmento de DNA contendo uma região interna ao sítio de inserção do plasmido Tn5. Para a obtenção do fragmento o tranposson foi extraído de células de E. coli DH5 $\alpha$-pir: Tn5 (QIAprep Spin Miniprip, QUIAGEN) e submetido a PCR os primers Tn5F (5'-ATTCAACGGGAAACGTCTTG-3) E Tn5R (5'ACTGAATCCGGTGAGAATGG-3') e purificado utilizando UltraClean ${ }^{\text {TM }}$ - up Kit (MOBIO Laboratories). A marcação da sonda e a hibridização foram realizadas utilizando o sistema de fosfatase alcalina termoestável (Amersham AlkPhos Direct ${ }^{\mathrm{TM}}$ Labeling and Detection Systems, GE HealthCare), a $55^{\circ} \mathrm{C}$ segundo as recomendações do fabricante. Todos os passos da hibridização foram realizados no forno de hibridização Hybridiser HB-2D (Techne). Após a hibridização a membrana foi lavada com tampão SSC (20x: NaCl, 3M; citrato de sódio, 0,3M; água MilliQ, $500 \mathrm{~mL}$; pH7) e documentada por autorradiografia.

\subsection{Análise de dados}

Tods as análise estatística dos experimentos foi realizada com o auxilio do programa $S A S-$ Copyright (C) 1989-1996 pelo SAS Institute Inc., Cary, NC, USA. 


\section{RESULTADOS}

\subsection{Antagonismo da linhagem TC3.4.2R3 contra diferentes espécies de Fusarium spp.}

Foram avaliados 4 fitopatógenos Fusarium spp. provenientes de diferentes culturas (Tabela 1), sendo observado que a linhagem TC3.4.2R3 foi capaz de inibir todos os fitopatógenos. Entretanto, a maior inibição ocorreu no antagonismo entre a linhagem B. seminalis TC3.4.2R3 e o fitopatógeno F. verticilioides FV-01-CTC (Figura 5). Assim, o fitopatógeno FV-01CTC foi utilizado para seleção dos potenciais mutantes defectivos no controle da fusariose.

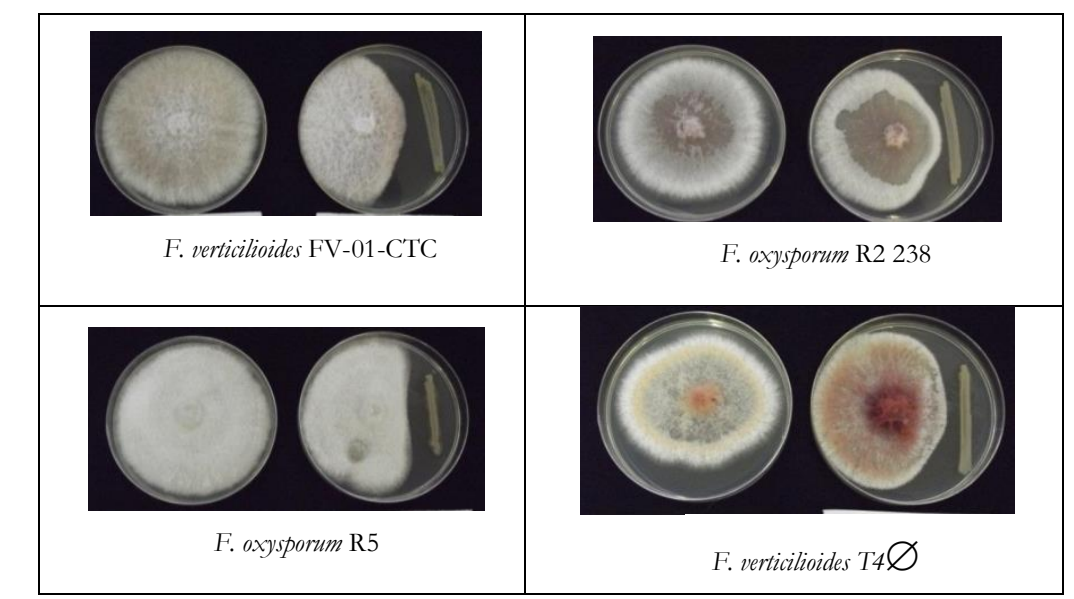

Figura 5: Diferentes níveis de inibição da linhagem Burkholderia seminalis TC3.4.2R3 sobre alguns fungos fitopatogênicos avaliados.

\subsection{Seleção dos mutantes quanto à perda da capacidade em produzir agentes antimicrobianos por meio do antagonismo}

Dentre os 1788 mutantes da biblioteca gerada a partir da linhagem B. seminalis TC3.4.2R3, foram avaliados 682 mutantes por meio da técnica de pareamento de cultura contra F. verticilioides FV-01-CTC. Foi observado que somente 8 mutantes apresentaram perda ou redução da capacidade de inibição contra o fitopatógeno avaliado. Os 8 mutantes que apresentaram diminuição visual clara do halo de inibição foram denominados internamente pelo grupo de pesquisa como: M3, M9, M15, M17, M20, M21, M25 e M28, sendo então selecionados para o ensaio semi-quantitativo.

No ensaio semi-quantitativo, foi observado que apenas o mutante M20 não apresentou diferença estatística a ser considerado realmente defectivo para o controle do crescimento do FV01-CTC comparado com a linhagem TC3.4.2R3 selvagem (Figura 6). Os demais mutantes 
apresentaram perda da capacidade de inibir in vitro o crescimento de FV-01-CTC em diferentes percentuais de inibição.

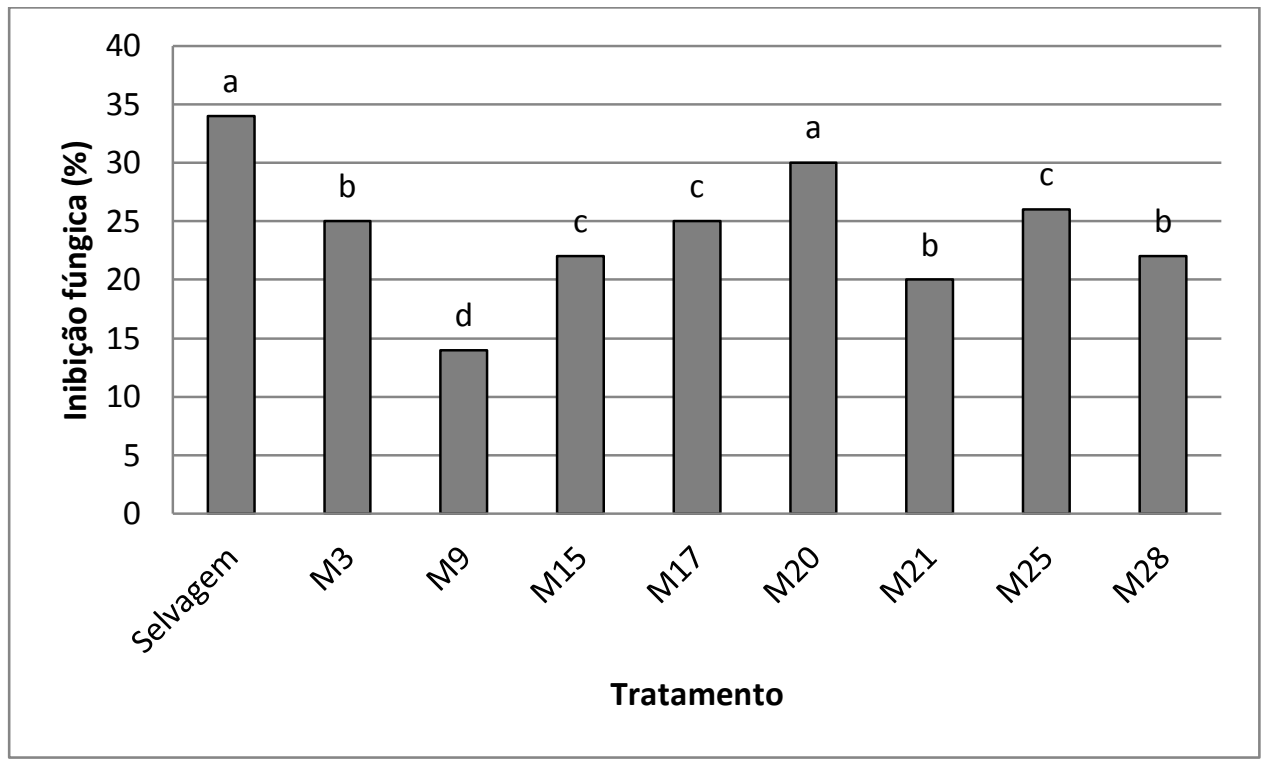

Figura 6: Antagonismo in vitro por pareamento da linhagem TC3.4.2R3 selvagem e seus mutantes contra o fitopatógeno F. verticilioides FV-01-CTC. A taxa de inibição foi mensurada após 7 dias de inoculação bacteriana $\left(10^{8}\right.$

UFC.mL-1). A taxa de inibição foi a média do crescimento da colônia sendo avaliadas 4 repetições (placas).

Tratamentos com a mesma letra não diferem estatisticamente $(\mathrm{P}>0,05)$ de acordo com o teste de Tukey.

\subsection{Caracteriação dos compsotos produzidos pela linhagem TC3.4.2R3 e seus mutantes defectivos no controle de $\boldsymbol{F}$. verticilioides FV-01-CTC}

Foi observado que todos os mutantes exceto M20, deixaram de inibir o patógeno FV-01CTC quando pareados em placa de Petri. Os componentes livre de célula do mutante M9 inibou o crescimento de FV-01-CTC. E, dentre os mutantes avaliados, somente o mutante M20 inibiu o crescimento de FV-01-CTC mesmo quando tratado termicamente (Tabela 2). Ressaltamos que a variável em análise neste experimento é o crescimento fúngico, logo quanto maior o percentual do crescimento fúngico menor será a inibição do mesmo. 
Tabela 2: Caracterização dos mutantes defectivos para a inibição de diferentes espécies de Fusarium quanto à capacidade de produzir agentes microbianos.

\begin{tabular}{cccc}
\hline Bactérias & $\begin{array}{c}\text { Controle } \\
\text { direto }\end{array}$ & Livre de células & Termoestável \\
\hline Selvagem & + & + & + \\
M3 & - & - & - \\
M9 & - & + & - \\
M15 & - & - & - \\
M17 & - & - & - \\
M20 & + & - & + \\
M21 & - & - & - \\
M25 & - & - & - \\
M28 & - & - & - \\
\hline
\end{tabular}

(+): inibição visível (-): não inibição

\subsection{Avaliação da atividade antagônica produzida pelos mutantes defectivos contra}

Fusarium spp.

Em relação a especificidade do mecanismos de inibição da fusariose, foi observado a especificidade dos mutantes de acordo com o Fusarium spp. avaliado. O mutante M15 inibiu o fitopatógeno R2 238 mas não apresentou inibição visível contra os outros Fusarium spp. avaliados. O mutante M20 apresentou inibição no crecimento micelial para os fitopatógenos FV01-CTC e T4 $\varnothing$ e defectivos para os demais. Já o mutante M25 apresentou inibição para o fitopatógeno T4 $\varnothing$ sendo defectivo para os demais fitopatógenos avaliados segundo resultado obtido.

Tabela 3: Caracterização dos mutantes defectivos para a inibição de diferentes espécies de Fusarium quanto à capacidade de produzir agentes microbianos.

\begin{tabular}{c|cccc}
\hline BACTÉRIAS & FV-01-CTC & R2 & R5 & T4 $~$ \\
\hline Selvagem & + & + & + & + \\
M3 & - & - & - & - \\
M9 & - & - & - & - \\
M15 & - & + & - & - \\
M17 & - & - & - & - \\
M20 & + & - & - & + \\
M21 & - & - & - & - \\
M25 & - & - & - & + \\
M28 & - & - & - & - \\
\hline
\end{tabular}

(+): inibição visível (-): não inibição 


\subsection{Caracterização molecular dos mutantes selecionados}

\subsubsection{Confirmação da inserção do transposon Tn5 por análise de PCR}

Por meio da PCR para a detecção do segmento do Tn5 utilizando os primers Tn5F e Tn5R foi demonstrado que todos os mutantes selecionados apresentavam o fragmento esperado de 399 pb. Foi utilizado o DNA da linhagem selvagem TC3.4.2R3 como controle negativo. Como controle positivo foi utilizado o DNA do plasmídeo Tn5 confirmando a especificidade dos primers utilizados (Figura 7).

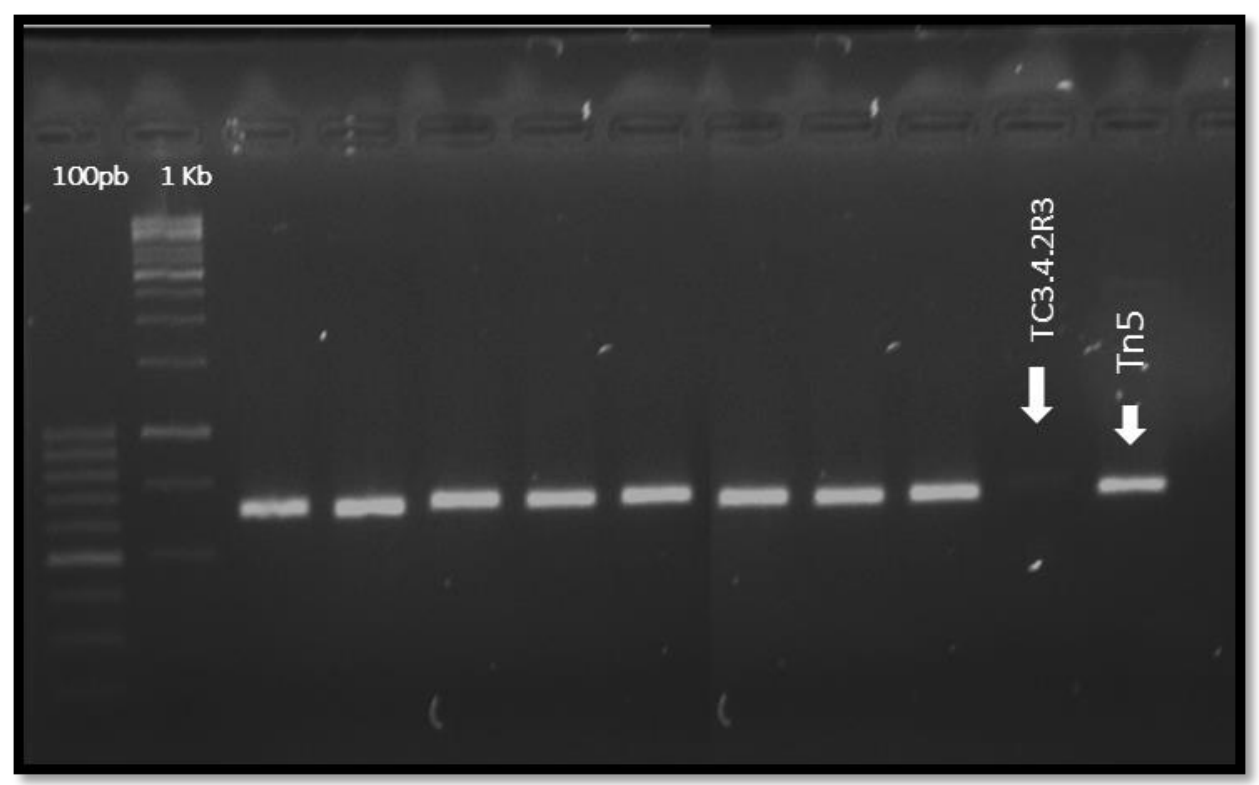

Figura 7: Amplificação da região do trasnposon com os primers Tn5F e Tn5R ) (WANG et al., 2008) a partir do DNA extraído dos 8 transformantes da linhagem B. seminalis TC3.4.2R3 que apresentaram alteração na atividade antifúngica. O transposon Tn5 extraído de E. coli DH5 $\alpha$-pir:Tn5 foi utilizado como controle positivo. Não houve amplificação no DNA genômico da linhagem selvagem. O marcador de pares de base 100pb e o marcador de peso molecular $1 \mathrm{~Kb}$ estão posicionados na lateral a esquerda do gel de agarose. A ordem das amostras da esquerda para a direita é: M3, M9, M15, M17, M20, M21, M25, M28 (mutantes), selvagem, TN5 e controle da reação de PCR.

\subsubsection{Clonagem, sequenciamento e análise das regiões flanqueadoras do transposon Tn5}

Com o objetivo de identificar os genes nocauteados pelo transposn nos mutantes da linhagem TC3.4.2R3 que apresentaram perda da inibição de FV-01-CTC, as regiões flanqueadas contendo o transposon Tn5 foram clonadas em E. coli DH5 $\alpha$-pir e o DNA plasmidial extraído e 
enviado para sequenciamento (Figura 8). Foram enviadas para o sequenciamento 16 amostras dos 8 mutantes selecionados (duas de cada) utilizados nos testes anteriores. Fragmentos da jusante e a montante com a utilização dos primers KAN-2 FP-1 e R6KAN-2 RP-1. Entretanto, dentre as 16 amostras enviadas conseguimos um sequenciamento de qualidade de 10 amostras.

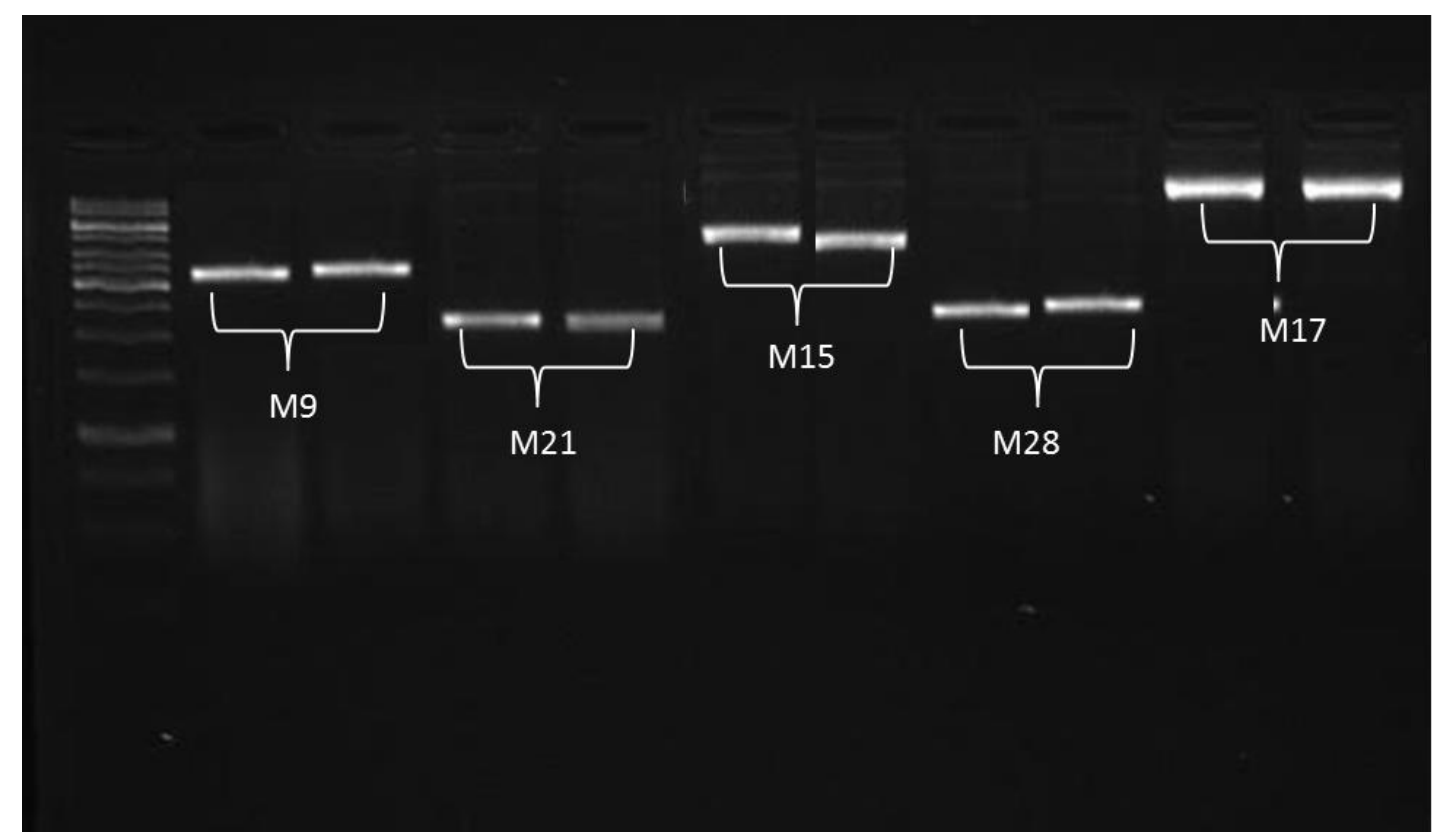

Figura 8: DNA plasmidial contendo o transposon Tn5 extraído de células de E. coli DH5-pir e enviadas para sequenciamento a jusante e a montante utilizando os primers KANFP-1 e KANRP-2 que anelam nas extremidades do transposn.

O resultado da análise dos mutantes TC3.4.2R3 defectivos no controle de Fusarium spp. permitiu a identificação de genes associados ao ciclo de nitrogênio, transportador celular dentre outras possíveis. As sequencias flaqueadoras sequenciadas de cada mutante apresentaram a mesma identidade quando blastadas. Os mutantes M15 e M28 mostraram nocaute do gene codificador da glutamato sintase. Os mutantes M9 e M21 apresentaram mutação no gene codificador da FAD. Também houve o nocaute do gene codificador da proteína TolB (mutante M17). Os demais mutantes cujos genes nocauteados não foram sequenciados, serão avaliados $a$ posteriori (Tabela 4). 
Tabela 4: Análise das regiões flanqueadoras do transposon de mutantes de B. seminalis TC3.4.2R3, que apresentaram defectividade no controle do crescimento do F. verticilioides FV-01-CTC.

\begin{tabular}{|c|c|}
\hline Mutante & $\begin{array}{c}\text { (Blast } X) \\
\text { Identificação, similaridade, E value e no de acesso }\end{array}$ \\
\hline M15 & $\begin{array}{c}\text { glutamate synthase } \\
(95 \%, 1 \mathrm{e}-26, \mathrm{ABF77603.1)}\end{array}$ \\
\hline M21 & $\begin{array}{c}\text { FAD-linked oxidase } \\
(99 \%, 5 e-52, \underline{\text { KOR18682.1 })}\end{array}$ \\
\hline M28 & $\begin{array}{l}\text { Ferredoxin-dependent glutamate synthase } 1 \\
\qquad(99 \%, 1 \mathrm{e}-62, \text { POM19843.1) }\end{array}$ \\
\hline M9 & $\begin{array}{c}\text { FAD-linked oxidase } \\
(96 \%, 1 \mathrm{e}-45, \text { KOR18682.1) }\end{array}$ \\
\hline M17 & $\begin{array}{c}\text { TolB } \\
(100 \%, 5 e-43, \text { WP } 034187207.1\end{array}$ \\
\hline
\end{tabular}

Todas as sequências de DNA dos mutantes identificados apresentaram alta similaridade e todas as amostras compatíveis com espécies do gênero Burkholderia.

\subsection{Análises in silico dos mutantes M15, M17 e M28 da linhagem TC3.4.2R3}

As seqências dos genes glutamato sintase, FAD e TolB provenientes da linhagem TC3.4.2R3 foram analisados in silico quanto a presença de domínios putativos.

O sequenciamento das regiões flanqueadoras do transposon Tn5 no mutante M15 mostrou a inserção na região intergênica ao gene codificador da glutamato sintase. O domínio funcional conservados desse gene nocauteado encontra-se aproximadamente de 200-280 pb, sendo obtida a mesma predição independente do banco de dados acessado (Tabela 5). 
Tabela 5: Descriçao da identidade do gene mutato corresponde a glutamato sintase em diferentes bancos de dados

\begin{tabular}{|c|c|c|c|c|}
\hline Nome & Acesso & Descrição & Intervalo & E-value \\
\hline GltS_FMN & Cd02808 & $\begin{array}{c}\text { Glutamate synthase (GltS) FMN-binding } \\
\text { domain. GltS is a complex iron-sulfur } \\
\text { flavoprotein }\end{array}$ & $200-280$ & $1.54 \mathrm{e}-06$ \\
\hline Glu_synthase & pfam01645 & $\begin{array}{l}\text { Conserved region in glutamate synthase; This } \\
\text { family represents a region of the glutamate }\end{array}$ & $209-280$ & $2.85 e-06$ \\
\hline GltB2 & COG0069 & $\begin{array}{l}\text { Glutamate synthase domain } 2 \text { [Amino acid } \\
\text { transport and metabolism]; }\end{array}$ & $200-280$ & $2.93 e-06$ \\
\hline gltB & PRK11750 & glutamate synthase subunit alpha; Provisional & $191-280$ & $2.78 \mathrm{e}-05$ \\
\hline GOGAT_sm_gam & TIGR01317 & $\begin{array}{c}\text { glutamate synthases, NADH/NADPH, small } \\
\text { subunit; This model represents one of three } \\
\text { built for }\end{array}$ & $116-199$ & $7.24 \mathrm{e}-0$ \\
\hline
\end{tabular}

No mutante M17 foi nocauteado o gene codificador da proteína TolB. O domínio conservado desse gene encontras-se $3-224$ pb. Foi encontrada a superfamília DPPIV_N (pepitidases de serina). A família TolB_N é uma proteína putativa sendo um componente periplasmático essencial para o sistema de translocação dependente (Tol-Pal system.) (Tabela 6).

Tabela 6: Descriçao da identidade do gene mutato correspondente a proteína TolB em diferentes bancos de dados

\begin{tabular}{|c|c|c|c|c|}
\hline Nome & Acesso & Descrição & Intervalo & E-value \\
\hline TolB & PRK02889 & Proteína de translocação TolB & $3-224$ & $9.60 e-33$ \\
\hline TolB_N & pfam04052 & $\begin{array}{c}\text { TolB é um essencial componente } \\
\text { periplasmatica }\end{array}$ & $3-224$ & $6.39 \mathrm{e}-17$ \\
\hline propeller_TolB & TIGR02800 & Sistema Tol-Pal proteína de reparo ToIB & 3-221 & $4.04 \mathrm{e}-12$ \\
\hline TolB & COG0823 & $\begin{array}{l}\text { Componente periplasmatico do sistema } \\
\text { Tol de transporte de biopolimeros }\end{array}$ & $15-218$ & $1.55 \mathrm{e}-09$ \\
\hline
\end{tabular}

\subsection{Análise in silico de metabólitos secundários produzidos por Burkholderia}

\section{seminalis linhagem TC3.4.2R3}

Com a utilização do programa antiSMASH verificamos 18 clusters gênicos potencialmente envolvidos na biosíntesse de metabólitos secundários identificados no genoma da linhagem 
TC3.4.2R3 (Tabela 7). Foram identificados clusters relacionado com a síntese de ectoina que apresenta importantes funções como proteção de raios ultravioleta e estresse hídrico. Foi identificado clusters relacionados a síntese de bacteriocinas e fosfanato. Também foram identificados clusters gênicos responsáveis pela biossíntese dos seguintes metabólitos secundários: terpeno, T1 pks, Arylpolyene, Hserlactone e NRPs. Nenhum desses foram observados como nocauteados nos mutantes que selecionamos neste trabalho.

Tabela 7: Clusters gênicos de metabólitos secundários de Burkholderia seminalis TC3.4.2R3 obtidos por meio do do banco de dados antiSMASH (Antibiotics SecondaryMetabolic Analysis Shell)

\begin{tabular}{|c|c|c|c|}
\hline Cluster & Produto & $\begin{array}{c}\text { Contig (N. de acesso no } \\
\text { NCBI) }\end{array}$ & $\begin{array}{c}\text { Localização do cluster } \\
\text { gênico }\end{array}$ \\
\hline Cluster 1 & Ectoine & Contig 2 (LAEU01000002) & $125937-136335$ \\
\hline Cluster 2 & Terpene & Contig 3 (LAEU01000003) & $201908-223947$ \\
\hline Cluster 3 & Bacteriocin & Contig 4 (LAEU01000004) & $244016-257057$ \\
\hline Cluster 4 & Nrps & Contig 5 (LAEU01000005) & $59406-114051$ \\
\hline Cluster 5 & Phosphonate & Contig 6 (LAEU01000006) & $3778-45463$ \\
\hline Cluster 6 & Terpene & Contig 6 (LAEU01000006) & $179395-200459$ \\
\hline Cluster 7 & Nrps & Contig 8 (LAEU01000008) & $10228-63008$ \\
\hline Cluster 8 & Terpene & Contig 10 (LAEU01000010) & 1916743268 \\
\hline Cluster 9 & Otherks & Contig 11 (LAEU01000011) & $1-32617$ \\
\hline Cluster 10 & Terpene & Contig 11 (LAEU01000011) & $64038-85120$ \\
\hline Cluster 11 & Bacteriocin & Contig 11 (LAEU01000011) & $157010-167825$ \\
\hline Cluster 12 & Terpene & Contig 20 (LAEU01000020) & $1-16821$ \\
\hline Cluster 13 & Terpene & Contig 21 (LAEU01000021) & $38902-59936$ \\
\hline Cluster 14 & Hserlactone & Contig 21 (LAEU01000021) & $67684-88292$ \\
\hline Cluster 15 & T1pks & Contig 25 (LAEU01000025) & $15920-63548$ \\
\hline Cluster 16 & Other & Contig 27 (LAEU01000027) & $1-29126$ \\
\hline Cluster 17 & Terpene & Contig 33 (LAEU01000033) & $56300-77370$ \\
\hline Cluster 18 & Arylpolyene & Contig 34 (LAEU01000034) & $33932-75182$ \\
\hline
\end{tabular}

\subsection{Caracterização dos mutantes para glutamato sintase e TolB avaliados na inibição do crescimento do patógeno $F$. verticilioides FV-01-CTC}

Os mutantes selecionados caracterizados para a perda da atividade da glutamato sintase (M15, MR3), e a linhagem restituída com o gene original da glutamato (2gg) e a proteína TolB (M17) foram avaliados quanto ao antagonismo de F. verticilioides FV-01-CTC. Foi observado que a 
linhagem restituída $2 \mathrm{gg}$ apresenta níveis de controle do crescimento do fungo maior do que a dos outros mutantes entretanto inferior à linhagem selvagem TC3.4.2R3 (Figura 9).

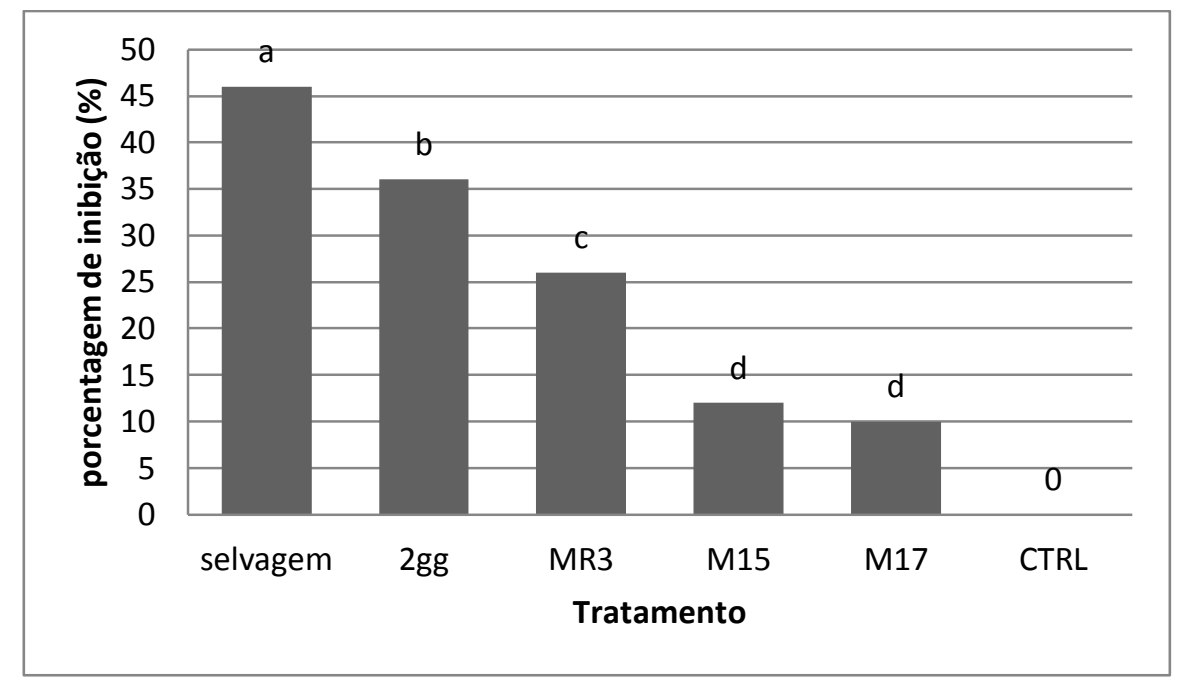

Figura 9: Avaliação do teste de antagonismo por pareamento in vitro da linhagem selvagem e dos mutantes M15 e M17 obtidos por meio da inserção do trnsposson Tn5, e pelos mutantes obtidos por troca alélica cepa com silenciamento do gene do glutamato (MR3) e a cepa com o gene silenciado mais sua complementariedade (2gg) contra o fungo F. verticilioides FV-01-CTC. A taxa de inibição foi mensurada após 7 dias de inoculação e a média do crescimento da colônia foi avaliadas com 4 repetições (placas). Tratamentos com a mesma letra não diferem estatisticamente $(\mathrm{P}>0,05)$ de acordo com o teste de Tukey.

\subsubsection{Comparação da curva de crescimento entre a linhagem TC3.4.2R3 selvagem e seus mutantes em tempo determinado}

Com a exceção da linhagem selvagem TC3.4.2R3, os demais mutantes cresceram em meio de cultura contendo seus respecivos antibióticos para seleção. Mesmo com a presença de antibóitco não houve uma diferença significativa do crescimento das linhagens mutadas em relação a linhagem selvagem TC3.4.2R3 (Figura 10). 


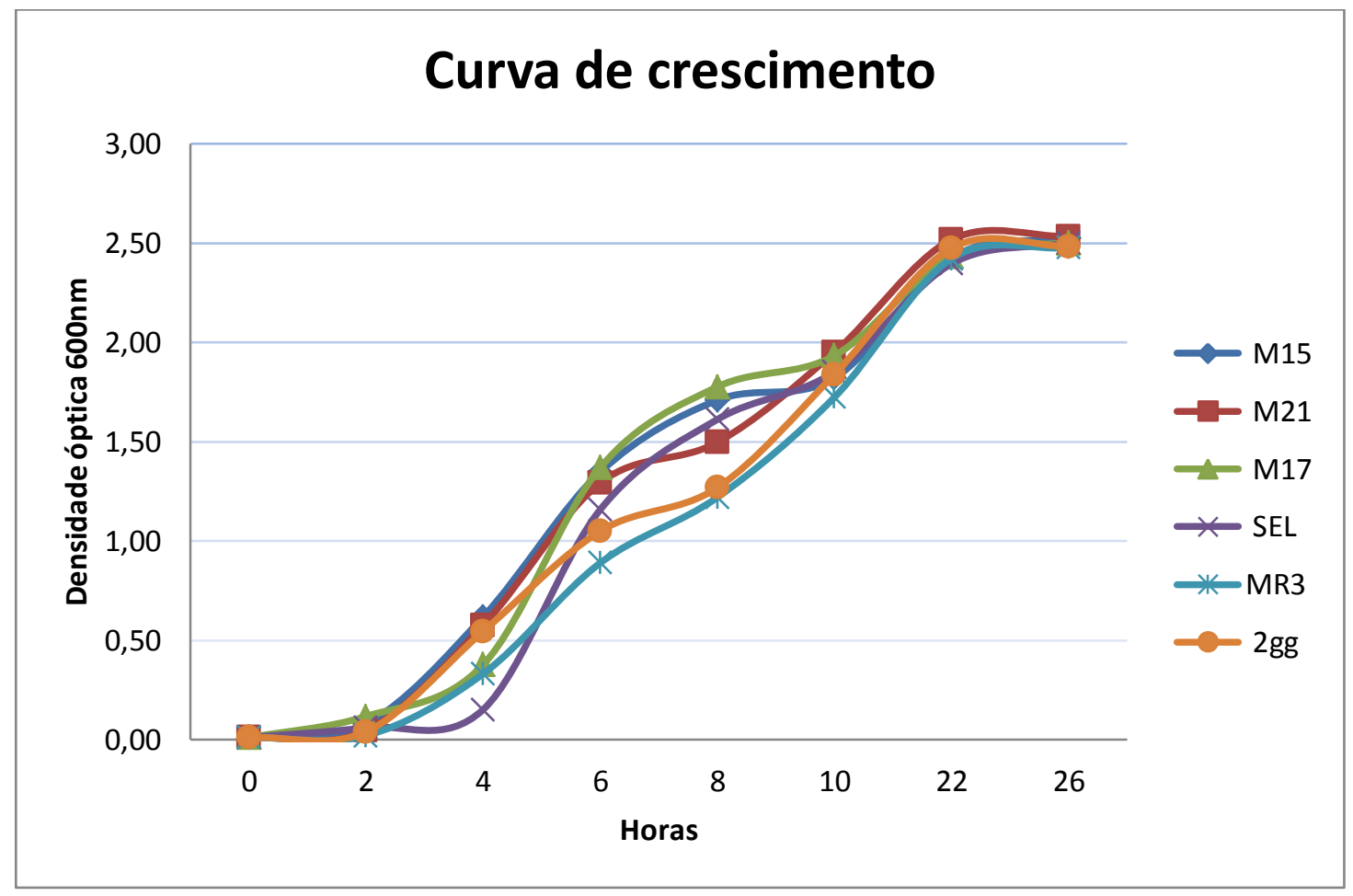

Figura 10: Curvas de crescimento da linhagem TC3.4.2R3 selvagem e seus mutantes em meio cultura LB. Sendo suplementado da seguinte forma: M15 e M17 suplementado com canamicina $200 \mu \mathrm{g} / \mathrm{mL}$; MR3 foi suplementado com $50 \mu \mathrm{g} / \mathrm{mL}$ de cloranfenicol; e o mutante $2 \mathrm{gg}$ suplementdo com $50 \mu \mathrm{g} / \mathrm{mL}$ de cloranfenicol mais $200 \mu \mathrm{g} / \mathrm{mL}$ de canamicina. Os dados mostrados são representativos de 3 repetições por tratamento sendo a leitura realizada em espectrofotômetro a uma $\mathrm{OD}_{600} \mathrm{~nm}$ em diferentes tempos.

\subsection{Análise de Southern Blot}

Para a análise de Southern Blot utilizamos os mutantes M15 e M17 para verificar o número de cópias que foram inseridas no genoma. A determinação do número de cópias do transposon foi avaliada utilizando um fragmento de 399pb do transposon como sonda para os dois mutantes selecionados. Após a análise, o mutante M15 apresentou somente uma banda de hibridização indicando que a inserção do transposon foi única. E o mutnte M17 também apresentou uma única banda. Nenhum sinal de hibridização foi observado para a linhagem selvagem TC3.4.2R3. A diferença nos tamanhos das bandas de hibridização indica que a inserção do transposon ocorreu em regiões próximas porém distintas do genoma da linhagem TC3.4.2R3. 


\section{DISCUSSÃO}

Em virtude dos prejuízos causados pelo fungo do gênero Fusarium e ao crescente interesse pela utilização de métodos de controle não tão agressivos ao meio ambiente e tão honeroso, agricultores e pesquisadores passaram a considerar o uso do controle biológico para o controle de doenças. Uma vez que, com a utilização de microrganismos antagônicos, é possível proporcionar diferentes níveis de controle em diversas doenças (PUNJA \& UTKHEDE, 2003).

As bactérias associadas às plantas podem ser agrupadas em bactérias que incluem bactérias rizosféricas (nas proximidades da raiz) e rizoplânicas (na superfície da raiz) e bactérias endofíticas. O termo "bactérias endofíticas" é referido àquelas bactérias que colonizam o interior das partes da planta, raiz, caule ou sementes sem causar nenhum efeito prejudicial na planta hospedeira (HALLMANN et al., 1997; LACAVA et al., 2004; CHRISTINA et al., 2013 ).

Estudos apontam que as bactérias endofíticas e rizobactérias apresentam grande importância no cenário biotecnológico como peças chaves na promoção de crescimento e controle de doenças e pragas (BERG \& HALLMANN, 2006; DUDEJA, 2016). Estudos voltados para análise molecular destes microrganismos vêem crescendo nos últimos tempos visando uma melhor compreensão da associação benéfica que existe entre microrganismo e planta (DUDEJA, 2016).

Espécies do gênero Burkholderia apresentam alta versatilidade ecológica e diferentes perfis de interação no ambiente (MENDES et al., 2007). Essas interações podem causar doenças em plantas e animais, mas também podem ser benéficas para algumas plantas, promovendo seu crescimento e suprimindo ataques de doenças de fitopatógenos devido a produção de biomoléculas com atividade antimicrobiana (LUVIZOT'TO et al., 2010). Embora alguns membros do gênero sejam patógenos ou associados há alguma doença em seus hospedeiros, a grande maioria das espécies associadas as plantas não são patogênicas e podem apresentar uma interação neutra ou benéfica com seus hospedeiros (ARAUJO et al., 2016).

Burkholderia spp. tem sido estudadas quanto a capacidade na produção de sideróforos, ácido indol acético, solubilização de fosfato, produção de metabólitos antifúngicos e antibacteriano: pirrolnitrina, fenazina, cepacina, cepaciamida, cepacidina (QUAN et al. 2006; MOREIRA et al., 2016), sendo responsáveis pelo controle de patógenos de inúmeras culturas (BACH et al., 2016; SANDANAKIROUCHENANE et al., 2017).

O efeito do biocontrole pode estar ligado a ação antagonística de microrganismos por síntese de antibióticos com efeito fungicida como por exemplo enzimas que degradam a parede celular. Nesta busca, pesquisas vêm demonstrando que a utilização de microrganismos de 
rizosfera pode atuar como um antagonista natural em uma gama de agentes patogênicos de plantas (AL-MUGHRABI, 2010; PÉREZ-MONTAÑO et al., 2014).

Levando em consideração o histórico bibliográfico do gênero Burkholderia em produzir agentes antimicrobianos, a linhagem TC3.4.2R3 da rizosfera de cana-de-açúcar foi selecionada para estudos mais aprofundados sobre as possíveis funções gênicas envolvidas no processo do controle da fusariose mais especificamente em F. verticilioides FV-01-CTC.

$\mathrm{Na}$ avaliação do teste de antagonismo por pareamento a bactéria selvagem apresentou inibição clara contra as espécies de Fusarium testadas (F. oxysporum R5, F. oxysporum R2 238 F. verticilioides FV-01-CTC, F. verticilioides T4 $\varnothing$ ). Resultados similares de controle biológico inicialmente in vitro de diferentes patógenos, tem sido publicados com outras espécies do gênero Burkholderia, mostrando a eficácia no controle biológico de severas doenças causadas por fungos como Botrytis cinerea, Fusarium oxysporum, Phytium, Rhizoctonia solani que causam respectivamente doenças como podridão da maçã, murcha de fusário em tomate, podridão da raiz em ervilha, dentre outras(CARTWRIGHT \& BENSON, 1995; KANG et al. 1998; SIJAN \& DIKIN, 2005).

Parke \& Rand (1991) relataram que sideróforos sintetizados pelo gênero Burkholderia constituem uma opção viável para biocontrole, pois a planta pode suprimir o crescimento de patógenos pela retirada do ferro daquele ambiente, visto que é um fator limitante para o crescimento de muitos agentes patogênicos na rizosfera. No trabalho realizado por Luvizzotto et al. (2010) com a linhagem TC3.4.2R3 foi observado a capacidade da produção de sideróforo por este microrganismo e o teste para a avaliação de antagonismo mostrou um controle sobre $F$. verticilioides e Xanthomonas albilineans os quais são patógenos de importância para a cultura de cana de açúcar. Mendes et al. (2007) verificaram a capacidade de produção de pirrolnitrina por TC3.4.2R3, que é um metabólito antifúngico com atividade antagonista contra uma grande variedade de fungos patogênicos de plantas e até patogênicos humanos. Soria et al., (2012) realiazaram testes por pareamento com as bactérias Bacillus subtilis e Burkholderia sp. onde foi observado atividades antagonística para o fitopatógeno F. circinatum, sendo comprovada pela formação de halo de inibição entre bactérias e fungo. Estes dados corroboram com nosso estudo mostrando o grande potencial de controle biológico pode ser encontrado no gênero Burkholderia em especial linhagem TC3.4.2R3.

Poucos são os estudos que visam identificar e caracterizar os genes responsáveis por tal controle. Visto tamanho potencial, é de suma importância estudar os mutantes defectivos no controle da doença devido à possibilidade de conhecer a função gênica e o produto responsável pelo controle biológico. Neste intuito, utilizamos então a biblioteca de mutantes da linhagem TC3.4.2R3 (ARAUJO et al., 2016) e dentre os 1788 analisamos 682 mutantes. 
Zhou et al., (2018) identificaram e caracterizaram um gene glutamato sintase MoGLT1 em Magnaporthe oryzae fungo que ataca arroz. O gene MoGLT1 foi constitutivamente expresso, mas apresentou o maior nível de expressão em apressórios. A supressão do MoGLT1 resultou em uma redução significativa na conidiação e virulência. Os mutantes DMoglt1 eram defeituosos na penetração do apressório, na diferenciação e disseminação de hifas em células vegetais. Com a restituição do gene no mutante defeituoso a virulência do fungo era restituída, mostrando assim que gene MoGlt1 é importante para patogênese e desenvolvimento no fungo na cultura do arroz.

Gallagher et al., (2013) construíram uma biblioteca de mutantes com quase 42.000 mutantes únicos utilizando a bactéria Burkholderia thailandensis, um substituto de baixa virulência para o agente causador da melioidose (Burkholderia pseudomallei). A biblioteca foi gerada usando transposon Tn5 e criaram uma biblioteca secundária com dois genes por mutante, para a qual a maioria dos locais de transposon foi confirmada por resequenciamento. O intuito da criação destas bibliotecas foi facilitar a triagem de mutantes abrangentes para servir de cepas testes para estudos posteriores com as associações genótipo-fenótipo.

Dentre os mutantes avaliados da linhagem TC3.4.2R3, foram encontrados 8 mutantes defectivos na inibição contra o F. verticilioides FV-01-CTC. Esses foram melhor investigados. A avaliação semi-quantitativa por pareamento demonstrou que houve reversão do fenótipo no mutante M20. Este resultado mostra a importância da repetição do experimento e a comprovação por meio da análise estatística para a validação de resultados qualitativos.

O ensaio de termoestabilidade demonstrou que mesmo após a autoclavagem a linhagem selvagem e o mutante M20 continuaram inibindo o patógeno FV-01-CTC. De los SantosVillalobos et al. (2012) estudaram a atividade antagônica das bactérias Burkholderia cepaccia XXVI e Bacillus sp contra o fungo Colletotrichum gloeosporioides utilizando o teste de metabólitos termoestável em diferentes temperaturas. Os autores demosntraram que os metabólitos de B. cepaccia XXVI quando submetidos a temperaturas superior a $70^{\circ} \mathrm{C}$ sofria uma possível degradação térmica diminuindo os efeitos de inibição. Porém o mesmo resultado não foi visto para com Bacillus sp., onde os autores sugerem que o metabólito produzido por este isolado seja o responsável pela inibição do patógeno o qual seria resistente a degradações térmicas à altas temperaturas. Provavelmente a linhagem TC3.4.2R3 produz compostos termoestáveis relacionados ao controle de F. verticilioides FV-01-CTC.

Foi observado que a linhagem selvagem e o mutante M9 continuam inibindo o fitopatógeno no teste livre de células. Kim et al., (2017) utilizando a técnica de metabolitos livre de células, avaliaram 4 linhagens de Paenibacillus polymyxa quanto ao controle de Cylindrocarpon destructans (fungo causador de doença em videira), onde somente uma linhagem promoveu 
inibição significativa do fitopatógeno. Ji et al. (2010), estudaram o efeito antagonista de metabólito livre de células de espécies de Bacillus sp. contra F. incarnatum. Os autores utilizaram duas metodologias: uma com a utilização de discos de papel e outro com diferentes dosagens da suspenção bacteriana, a fim de verificar a inibição da germinação do conídio do fungo. A inibição foi vista claramente por uma zona clara ao redor dos discos com o metabólito e com a suspensão de células. Foi observado que a zona de inibição foi maior no tratamento com suspensão bacteriana e que não houve diferença estatística significativa entre os tratamentos com a suspenção.

Da Silva Araújo et al., (2017) investigaram por espectrometria de massas de ionização (MALDI-MSI) a composição de metabólitos secundários de B. seminalis TC3.4.2R3 e a inibição Fusarium oxysporum. O sideróforo pioquelina e o ramnolipídeo Rha-Rha-C15-C14 foram detectados na linhagem selvagem B. seminalis TC3.4.2R3 e também em seus mutantes porém estes com variações e apresentando rupturas em conjuntos de genes associados com o composto antimicrobiano. Duas micotoxinas foram produzidas por F. oxysporum durante a co-cultura com B. seminalis, sendo estas relacionadas com os metabólitos do mecanismo de defesa do fungo. Este resultado vem corroborar com os resultados obtidos no presente projeto, que demosntraram que a difusão de compsotos produzidos por TC3.4.2R3 sào capazes de inibir Fusarium spp.

A utilização diferentes técnicas nos ensaios de antagonismo se justifica, uma vez que, tanto a técnica utilizada, como a escolha do microrganismo antagônico podem modular o resultado da interação. Aparentemente, a cultura de filtrados livre de células da bactéria, inibiu melhor o crescimento do F. verticilioides FV-01-CTC em relação ao aos metabólitos bacterianos submetidos a autoclavagem mas não superou os resultados obtidos no teste de pareamento, demostrando que mais de um composto deve estar envolvido no potencial de controle biológico da TC3.4.2R3.

O comprovado potencial da linhagem selvagem TC3.4.2R3 em produzir diversos agentes antimicrobianos foi comprovado por meio dos diferentes genes nocauteados em T3.4.2R3 envolvidos do processo de antagonismo ao F. verticilioides FV-01-CTC. Ficou evidente que os genes codificadores glutamaro sintase, TolB e FAD são diretamente ou indiretamente relacionados so controle de FV-01-CTC. Esses compostos também estão relacionados ao controle de outros Fusarium app.

As vias de sinteses de glutamato compartilham muitas propriedades funcionais. No entanto, três classes de glutamato-sintases são definidas com base em suas seqüências de aminoácidos e a natureza do doador de elétrons (VANONI \& CURTI, 1999), primeira: o GltS dependente de NADPH bacteriano consiste em duas subunidades (subunidade $\alpha$ de 
aproximadamente $150 \mathrm{kDa}$ e subunidade $\beta$ de aproximadamente $50 \mathrm{kDa}$ ). Estes formam a holoenzima $\alpha \beta$ cataliticamente ativa, que contém um FAD, um FMN e três agregados de ferroenxofre. Segunda: o GltS dependente de Ferredoxina é encontrado nas células fotossintéticas. Este tipo de GltS contém um cluster FMN e um 3Fe-4S e compartilha homologia considerável em toda a sua sequência com a subunidade $\alpha$ do GltS bacteriano. Terceira: Levedura, fungos e animais inferiores contêm uma cadeia única de GltS dependente de H de NAD (P) H de cerca de $200 \mathrm{kDa}$. É formado pela fusão de dois fragmentos, que são semelhantes às subunidades $\alpha$ e $\beta$ do GltS bacteriano, respectivamente. O GltS dependente de NADPH da bactéria fixadora de nitrogênio Azospirillum brasilense está entre as sintases de glutamato melhor caracterizadas (SAIKIA et al., 2012) . Mutantes auxotróficos de glutamina de A. brasilense, defeituosos na sintese de glutamato, liberam amônio sob condições de fixação de $\mathrm{N}_{2}$; estes mutantes não têm atividade de absorção de amônio (HARTMANN et al., 1984). Em mutantes prototróficos de A. brasilense resistente à metionina sulfoximina (MSX), ocorre a fixação constitutiva de $\mathrm{N}_{2}$, mas nenhuma molécula de amônio é liberada (HARTMANN, 1982). Com está informação, especulou-se que mecanismos para a liberação de compostos de nitrogênio está presente nas bactérias associadas a de fixação de N2, mas esta propriedade está sob a controle fisiológico dos fatores determinados pela planta (HARTMANN, 1988; LANA et al., 2012,). Apesar de bem descrito o papel da glutamato sintase no via do nitrogênio, ainda sào incipientes estudos relacioados ao seu papel no controle de fitopatógenos.

Nandineni et. al., 2004 relataram que em bactérias o glutamato não é somente precursor de outros aminoácidos, mas também está envolvido na osmorregulação e em alguns casos como precursor da biossíntese de ferro, como substrato de proteínas carreadoras e fonte de grupos amino para a produção de antibióticos e antitumorais. Sob condições limitantes de ferro, alguns dos biocontroladores secretam sideróforo, que quela ferro disponível de solo e, por vezes, de microrganismos coabitantes, privando os fungos patogênicos deste elemento (COMPANT et al., 2005). Talvez a menor produção de sideróforos por TC3.4.2R3 devido ao nocaute do glutamato sintase esteja relacionado ao controle de Fusarium spp., entretanto mais estudos devem ser realizados.

Outro papel do gltamato síntese produzido por TC3.4.2R3 que deve ser explorado é na promoção de crescimento de plantas. A homeostase do glutamato desempenha um papel vital no metabolismo central do nitrogênio e coordena várias funções metabólicas chaves. Trabalhos anteriores realizados com esta linhagem TC3.4.2R3 por Luvizotto et al., (2010) comprovaram a capacidade de fixação de nitrogênio com ensaio in vitro em com a utilização de primers especifícos para fixação de nitrogênio. Neste âmbito podemos concluir que a linhagem TC3.4.2R3 tem o 
gene que é expresso para a fixação de nitrogênio. Estudos relatam a sintese da glutamina, glutamato e amônia, é de grande importância para a manutenção dos níveis estacionários intracelulares os quais inibem a formação de apressórios nos fungos (MARROQUIN-GUZMAN \& WILSON, 2015).

Recentemente Zhou et al., (2018) realizaram estudo no controle do fungo Magnaporthe oryzae patógeno de arroz, onde caracterizaram um gene relacionado a síntese de glutamato (MoGLT1). Eles utilizaram uma estirpe selvegem do fungo, e um mutante defectivo e outro constitutivo com o gene MoGLT1. E verificaram que as estirpes com o gene ativo apresentaram maior nível de expressão em apressórios e a supressão deste gene resultou em uma redução significativa na condição de virulência, na penetração e formação de apressório. A falta do glutamato em TC3.4.2R3 pode indiretamente estar inibindo o controle de Fusarium spp.

O mutante M17 apresentou nocaute no gene codificador da proteína TolB que faz parte do sistema Tol-Pal, omplexo multiproteico encontrado no envelope celular de muitas bactérias gram-negativas (CASCALES et al., 2007). Até o momento, o papel celular da proteína TolB não é claro.No entanto, existem propostas para as diferentes funções que podem ser realizadas e utilizadas para benefício celeular. Os componentes do sistema Tol-Pal podem estar envolvidos na manutenção da membrana externa, uma vez que mutações nas proteínas TolB resultam em extravazamento o conteúdo do periplasma, assim como uma hipersensibilidade a alguns detergentes, antibióticos e outros agentes (LLOUBÈS et al., 2001). Podem também, desempenhar um papel na ancoragem da membrana externa à camada de peptidoglicano através das interações que ocorrem entre TolB, Pal, Lpp e OmpA (BOUVERET et al., 1995). Zhang et al., (2010) estudando o sistema Tol-Pal em E. coli comprovaram que a interação da proteína TolB no periplasma das células promovem o transporte do domínio citotóxico de colicina através do envelope celular. Evidenciando o papel exercido da proteína TolB na região membranar sendo responsável pela liberação de entrada e saída de diferentes moléculas.

As bacteriocinas ou colicinas são potentes antibióticos proteicos, com especificidade ditada por suas interações proteína-proteína dentro do envelope celular de bactérias gran negativas (PAIK et al., 2018). A translocação de bacteriocinas alvo para liberação celular é facilitada através da interação com componentes do sistema Tol-Pal entre eles a proteína TolB. A interação com o sistema é mediado por ligação no terminal $\mathrm{N}$ da bacteriocina usando porinas não específicas para passar pelo periplasma, onde são selecionados seus alvos (RASSAM et al., 2018).

Correlacionando estas informações, a bactéria B. seminalis TC3.4.2R3 produz bacteriocinas e outros compostos capazes de inibir o crescimento do Fusarium spp. que devem ser secretados 
pelo sistema Tol-Pal. A falta da proteína TolB no mutante M17 pode impedir a secreção desses compostos, tornando-o assim defectivo no controle de Fusarium spp.

Genes que codificam vias biossintéticas responsáveis pela produção de metabólitos secundários normalmente ficam próximos em uma certa posição no cromossomo e são referidos seu conjunto como "cluster gênico" (MEDEMA et al., 2015). Por meio do programa antiSMASH foi observavdo que no genoma parcial de B. seminalis TC3.4.2R3 apresenta 18 cluster gênico para a biossíntese de metabólitos secundários, a maioria deles envolvida na produção de terpeno (7 clusters). Entre os genes nocauteados não foi encontrado nenhum codificador para metabólitos secundários, entretanto o conhecimento da presença dos mesmo é importante para entender o papel indireto do TolB como possível componente secretor desses.

Os papeis biológicos e ecológicos para terpenos ainda são conhecidos (GERSHENZON \& DUDAREVA, 2007). A produção de NRPs gerou 2 cluster os quais são preditos produtos naturais muito diversificados, com uma gama extremamente ampla de atividades biológicas e propriedades farmacológicas. São muitas vezes toxinas, sideróforos e pigmentos (XU et al., 2012). $\mathrm{Na}$ produção de ectoina (1 cluster) um composto natural encontrado em várias espécies de bactérias. É um soluto que serve como uma substância protetora, agindo como um osmólito auxiliando os organismos a sobreviverem a um estresse osmótico extremo. Ectoína é encontrada em altas concentrações em microrganismos halofílicos e em uma ampla gama de bactérias gramnegativas e gram-positivas conferindo resistência ao estresse salino e à temperatura (PETERS et al., 1990; BEBLO-VRANESEVIC et al., 2017). Sendo de grande interesse para a indústria farmacêutica por ser um ingrediente ativo em produtos de cuidados com a pele e proteção solar (STÖVEKEN et al., 2011).

Dois clusters foram identificados na produção de bacteriocinas que se trata de uma proteína tóxica sintetizada por bactérias no intuito de inibir o crescimento de microrganismos sendo muito diverso estruturalmente, fisiologicamente e ecologicamente.

Um cluster identificado como hserlactone conhecido também como uma halmoserina lactona que está relacionado como um sinal químico de defesa, quórum sensi bacteriano permitindo que as células bacterianas regulem a expressão gênica dependendo da densidade populacional (HENSE et al., 2007,). Estes metabólitos são detectados em sua maior parte em quorum bacteriano gram-negativo (BAUER et al., 2004). Trabalho realizado por Wei et al., (2007) fizeram a deleção do gene proI, (responsável pela produção de halmoserina lactona em Pseudomonas fluorescens 2P24), a qual deixou o mutante defectivo na formação de biofilme, não colonizando a rizosfera de trigo comprometendo a capacidade de biocontrole contra patógenos. Já com a cepa restituída 
com gene pcoI a atividade de biocontrole se aproximou do nível da cepa tipo selvagem. Resultado semelhante ao obtido em nosso trabalho para o gene do glutamato.

Para o cluster arilpolieno foi encontrado somente 1 representante. Este metabólito é descritos como pigmentos bacterianos e sua estrutura é semelhante aos carotenóides encontrados em plantas (SCHÖNER et al., 2016). No trabalho de Schöner et al., (2016) foi relatado pela primeira vez que esta classe de pigmentos protege a bactéria de espécies reativas de oxigênio, similarmente ao que é conhecido pelos carotenóides.

Outro cluster identificado foi para fosfanato, que são ácidos fosfônicos compostos organofosforados. Ácidos fosfônicos, tipicamente manuseados como sais, são geralmente sólidos não voláteis e pouco solúveis em solventes orgânicos, mas solúveis em água e álcoois comuns. Muitos compostos comercialmente importantes são fosfonatos, incluindo o glifosato (STRUGER et al., 2015), o herbicida "Roundup" (CHEKAN et. al., 2016), e o ethephon, um regulador de crescimento de plantas amplamente utilizado (ZARAD et al., 2016). Em biologia e química medicinal, grupos fosfonato são usados como bioisoteres estáveis para fosfato, como no análogo de nucleotídeo antiviral, Tenofovir, um dos pilares da terapia anti- HIV (MACKMAN et al., 2010), hepatite B entre outros (MENÉNDEZ-ARIAS et al., 2014). Na natureza, as bactérias desempenham um papel importante na degradação dos fosfonatos devido à presença de fosfonatos naturais no meio ambiente, as bactérias desenvolveram a capacidade de metabolizar como fontes de nutrientes de fósforo voltado para o crescimento (HUANG et al., 2005). Os aminofosfonatos também podem ser usados como única fonte de nitrogênio por algumas bactérias (HUANG et al., 2005). Os polifosfonatos usados na indústria diferem muito dos fosfonatos naturais, como o ácido 2-aminoetilfosfônico, porque são muito maiores, carregam uma carga negativa alta e são complexados com metais. Testes de biodegradação com lodo de estações municipais de tratamento de esgoto com polifosfonatos não mostraram nenhuma indicação para qualquer degradação. No entanto, há cepas bacterianas capazes de degradar aminopolifosfonatos sob condições limitadas de fosforo (NOWACK, 2003).

Estes resultados mostram a gama de utilização dos metabólitos secundários que são gerados a partir da expressão gênica de clusters específicos da linhagem TC3.4.2R3 de B. seminalis e que devem ser melhor estudados por meio de nocaute sítio dirigido em etapas futuras.

Como observado no presente projeto, o uso da ténica de nocaute sítio dirigida foi de vital importância para validar o papel do glutamato no controle de Fusarium spp., visto que o mutante MR3 validou o dados obtidos com os mutante randômico M15.

Não foi conclusivo do papel direto dos genes nocauteados glutamato e proteína TolB no controle de Fusarium spp.. Esses genes como descrito previamante podem estar envolvidos em 
diversos processos fisiológicos na bactéria B. seminalis. Assim, o presente projeto abre novas perspectivas de estudo, certamente os mecanismos de controle da fusariose por B. seminalis TC3.4.2R3 é amplo e sinergistico não apresentando grande especificidade de acordo com a espécie fungica. Há uma enorme perspectiva em desvendar o papel do glutamato e TolB no controle de fitopatógenos. Além disso pela análise in silico do metabólitos secundários novos genes candidatos foram encontrados para futuros estudos com nocaute sítio dirigido. Finalmente os mutantes caracterizados, como exemplo o M15, pode ser fonte de novos estudos para o complexo entendimento da interação microrganismo-planta-patógeno.

Com estes resultados daremos continuidade ao trabalho com experimentos in vivo, para de verificar o papel do glutamato proveniente da linhagem TC3.4.2R3 na promoção de crescimento vegetal. 


\section{CONCLUSÃO}

Os resultados obtidos no presente trabalho permitem as seguintes conclusões:

1) A linhagem B. seminalis TC3.4.2R3 apresentou potencial em produzir compostos com atividades antifúngica in vitro, sendo capaz de controlar o crescimento de FV01-CTC;

2) A inibição de FV-01-CTC é realizada por meio de compostos termoestáveis e de componentes livres de células. Com tudo, o melhor resultado foi obtido com o antagonismo por meio do pareamento entre a colônia fúngica e a bacteriana.

3) O nocaute do gene glutamato sintase e TolB reduziram o potencial de controle in vitro do fitopatógeno FV-01-CTC pela linhagem TC3.4.2R3.

4) A linhagem TC3.4.2R3 possui pelo menos 18 clusters de metabólitos secundários que podem estar envolvidos na síntese de compostos antimicrobianos, promoteres de crescimento em plantas, biocontroladores de doenças e pragas, dentre outros. 


\section{REFERÊNCIAS}

Agrios, G. N. (2005). Plant diseases caused by fungi. Plant pathology, 4.

Alexandratos, Nikos et al. (2012). World agriculture towards 2030/2050: the 2012 revision. Rome, FAO: ESA Working paper.

Al-Mughrabi, K. I. (2010). Biological control of Fusarium dry rot and other potato tuber diseases using Pseudomonas fluorescens and Enterobacter cloacae. Biological Control, 53(3), 280-284.

Andreote, F. D., Gumiere, T., \& Durrer, A. (2014). Exploring interactions of plant microbiomes. Scientia agrícola, 71(6), 528-539.

Araújo, W. L. et al. (2016).Genome sequencing and transposon mutagenesis of Burkholderia seminalis TC3. 4.2 R3 identify genes contributing to suppression of orchid necrosis caused by B. gladioli. Molecular Plant-Microbe Interactions, 29 (6), 435-446.

Ashraf, Q. H.; Weil, D. N.; Wilde, J. (2013). The effect of fertility reduction on economic growth. Population and development review, 39(1), 97-130.

Azevedo, J. L., \& Araújo, W. L. (2007). Diversity and applications of endophytic fungi isolated from tropical plants. Fungi: multifaceted microbes, 1, 189-207.

Bach, E.; dos Santos Seger, G. D., de Carvalho Fernandes, G., Lisboa, B. B., \& Passaglia, L. M. P. (2016). Evaluation of biological control and rhizosphere competence of plant growth promoting bacteria. Applied soil ecology, 99, 141-149.

Bauer, W. D., \& Mathesius, U. (2004). Plant responses to bacterial quorum sensing signals. Current opinion in plant biology, 7(4), 429-433.

Beblo-Vranesevic, K., Galinski, E. A., Rachel, R., Huber, H., \& Rettberg, P. (2017). Influence of osmotic stress on desiccation and irradiation tolerance of (hyper)-thermophilic microorganisms. Archives of microbiology, 199(1), 17-28.

Berg, G. \& Hallmann, J. (2006). Control of plant pathogenic fungi with bacterial endophytes. Microbial root endophytes, p. 53-69.

Bevivino, A., Dalmastri, C., Tabacchioni, S., \& Chiarini, L. (2000). Efficacy of Burkholderia cepacia MCI 7 in disease suppression and growth promotion of maize. Biology and Fertility of Soils, 31(3-4), 225-231.

Bouveret, E., Derouiche, R., Rigal, A., Lloubes, R., Lazdunski, C., \& Benedetti, H. (1995). Peptidoglycan-associated lipoprotein-TolB interaction. A possible key to explaining the formation of contact sites between the inner and outer membranes of Escherichia coli. Journal of Biological Chemistry, 270(19), 11071-11077.

Brader, G., Compant, S., Mitter, B., Trognitz, F., \& Sessitsch, A. (2014). Metabolic potential of endophytic bacteria. Current opinion in biotechnology, 27, 30-37. 
Brogden, K. A. (2005). Antimicrobial peptides: pore formers or metabolic inhibitors in bacteria?. Nature reviews microbiology, 3(3), 238.

Burkhead, K. D., Schisler, D. A., \& Slininger, P. J. (1994). Pyrrolnitrin production by biological control agent Pseudomonas cepacia $\mathrm{B} 37 \mathrm{w}$ in culture and in colonized wounds of potatoes. Applied and environmental microbiology, 60(6), 2031-2039.

Carrer Filho, R., Dianese, É. D. C., \& Cunha, M. G. D. (2015). Suppression of Fusarium wilt in tomato plants by rhizobacteria from the Bacillus genus. Pesquisa Agropecuária Tropical, 45(3), 356-363.

Carrer, H.; Barbosa, A. L.; Ramiro, D. A. (2010). Biotecnologia na agricultura. Estudos avançados, 24(70), 149-164.

Cartwright, D. K., Chilton, W. S., \& Benson, D. M. (1995). Pyrrolnitrin and phenazine production by Pseudomonas cepacia, strain $5.5 \mathrm{~B}$, a biocontrol agent of Rhizoctonia solani. Applied microbiology and biotechnology, 43(2), 211-216.

Cascales, E., Buchanan, S. K., Duché, D., Kleanthous, C., Lloubes, R., Postle, K., \& Cavard, D. (2007). Colicin biology. Microbiology and molecular biology reviews, 71(1), 158-229.

Cheikhyoussef, A., Pogori, N., Chen, W., \& Zhang, H. (2008). Antimicrobial proteinaceous compounds obtained from bifidobacteria: from production to their application. International journal of food microbiology, 125(3), 215-222.

Chekan, J. R., Cogan, D. P., \& Nair, S. K. (2016). Molecular basis for resistance against phosphonate antibiotics and herbicides. MedChemComm, 7(1), 28-36.

Chełkowski, J. E. (1989). Formation of mycotoxins produced by Fusarium in heads of wheat, triticale and rye. In Fusarium (pp. 63-84).

Chiarini, L., Bevivino, A., Dalmastri, C., Tabacchioni, S., \& Visca, P. (2006). Burkebolderia cepacia complex species: health hazards and biotechnological potential. Trends in microbiology, 14(6), 277-286.

Christina, A., Christapher, V., \& Bhore, S. J. (2013). Endophytic bacteria as a source of novel antibiotics: an overview. Pharmacognosy reviews, 7(13), 11.

Compant, S., Duffy, B., Nowak, J., Clément, C., \& Barka, E. A. (2005). Use of plant growthpromoting bacteria for biocontrol of plant diseases: principles, mechanisms of action, and future prospects. Applied and environmental microbiology, 71(9), 4951-4959.

Cook, R. J., \& Baker, K. F. (1983). The nature and practice of biological control of plant pathogens. American Phytopathological Society.

da Silva Araújo, F. D., Araújo, W. L., \& Eberlin, M. N. (2017). Potential of Burkholderia seminalis TC3. 4.2 R3 as biocontrol agent against Fusarium oxysporum evaluated by mass spectrometry imaging. Journal of The American Society for Mass Spectrometry, 28(5), 901-907.

Davis, R. M., Colyer, P. D., Rothrock, C. S., \& Kochman, J. K. (2006). Fusarium wilt of cotton: population diversity and implications for management. Plant Disease, 90(6), 692-703. 
de los Santos-Villalobos, S., Barrera-Galicia, G. C., Miranda-Salcedo, M. A., \& Peña-Cabriales, J. J. (2012). Burkholderia cepacia XXVI siderophore with biocontrol capacity against Colletotrichum gloeosporioides. World Journal of Microbiology and Biotechnology, 28(8), 2615-2623.

de Souza, Rocheli et al. (2013). The effect of plant growth-promoting rhizobacteria on the growth of rice (Oyyza sativa L.) cropped in southern Brazilian fields. Plant and soil, 366(1-2), 585-603.

Domsch, K. H., Gams, W., \& Anderson, T. H. (1980). Compendium of soil fungi. Volume 1. Academic Press (London) Ltd.

Dordević, M., Vatchev, T., Girek, Z., Šević, M., Zečević, B., Zdravković, J., \& Ivanović, M. (2012). Reaction of different tomato cultivars toward race 1 of Fusarium oxysporum $\mathrm{f}$. sp. lycopersici. Genetika, 44(1), 109-118.

Dudeja, Surjit Singh (2016). Beneficial Effects and Molecular Diversity of Endophytic Bacteria in Legume and Nonlegumes. In: Microbial inoculants in sustainable agricultural productivity. Springer, New Delhi,. p. 245-256.

Duffy, B., Keel, C., \& Défago, G. (2004). Potential role of pathogen signaling in multitrophic plant-microbe interactions involved in disease protection. Applied and environmental microbiology, 70(3), 1836-1842.

El-banna, N., \& Winkelmann, G. (1998). Pyrrolnitrin from Burkholderia cepacia: antibiotic activity against fungi and novel activities against streptomycetes. Journal of Applied Microbiology, 85(1), 69-78.

Flores, P. S., Otoni, W. C., Dhingra, O. D., de Souza Diniz, S. P. S., Dos Santos, T. M., \& Bruckner, C. H. (2012). In vitro selection of yellow passion fruit genotypes for resistance to Fusarium vascular wilt. Plant Cell, Tissue and Organ Culture (PCTOC), 108(1), 37-45.

Fortunato, A. A., Rodrigues, F. Á., Baroni, J. C. P., Soares, G. C. B., Rodriguez, M. A. D., \& Pereira, O. L. (2012). Silicon suppresses Fusarium wilt development in banana plants. Journal of Phytopathology, 160(11-12), 674-679.

Freitas, L. G., Neves, W. S., Fabry, C. S., \& Marra, B. M. (2005). Isolamento e Seleção de Rizobactérias para Controle de Nematóides formadores de Galhas (Meloidogyne spp.) na Cultura do Tomateiro1. Nematologia Brasileira, 29(2), 215-220.

Gallagher, L. A., Ramage, E., Patrapuvich, R., Weiss, E., Brittnacher, M., \& Manoil, C. (2013). Sequence-defined transposon mutant library of Burkholderia thailandensis. MBio, 4(6), e0060413.

Geiser, D. M., del Mar Jiménez-Gasco, M., Kang, S., Makalowska, I., Veeraraghavan, N., Ward, T. J., ... \& O'donnell, K. (2004). FUSARIUM-ID v. 1.0: A DNA sequence database for identifying Fusarium. European Journal of Plant Pathology, 110(5-6), 473-479.

Gershenzon, J., \& Dudareva, N. (2007). The function of terpene natural products in the natural world. Nature chemical biology, 3(7), 408.

Ghatak, K. L. (2011). Techniques and Methods in biology. PHI Learning Pvt. Ltd. 
Godlewska, R., Wiśniewska, K., Pietras, Z., \& Jagusztyn-Krynicka, E. K. (2009). Peptidoglycanassociated lipoprotein (Pal) of Gram-negative bacteria: function, structure, role in pathogenesis and potential application in immunoprophylaxis. FEMS microbiology letters, 298(1), $1-11$.

Goryshin, I. Y., and Reznikoff, W. S. (1998). Tn5 in vitro transposition. Journal of Biological Chemistry, 273(13), 7367-7374.

Goswami, D., Handique, P. J., \& Deka, S. (2014). Rhamnolipid biosurfactant against Fusarium sacchari-the causal organism of pokkah boeng disease of sugarcane. Journal of basic microbiology, 54(6), 548-557.

Gupta, A. K., Baran, R., \& Summerbell, R. C. (2000). Fusarium infections of the skin. Current opinion in infectious diseases, 13(2), 121-128.

Hallmann, J., Quadt-Hallmann, A., Mahaffee, W. F., \& Kloepper, J. W. (1997). Bacterial endophytes in agricultural crops. Canadian Journal of Microbiology, 43(10), 895-914.

Hartmann, A. (1982). Antimetabolite effects on nitrogen metabolism of Azospirillum and properties of resistant mutants. Experientia Suppl, 42, 59-68.

Hartmann, A. (1988). Ecophysiological aspects of growth and nitrogen fixation in Azospirillum spp. Plant and Soil, 110(2), 225-238.

Hartmann, A., Kleiner, D., \& Klingmüller, W. (1984). Ammonium uptake and release by Arospirillum. In Advances in nitrogen fixation research (pp. 227-227). Springer, Dordrecht.

Hense, B. A., Kuttler, C., Müller, J., Rothballer, M., Hartmann, A., \& Kreft, J. U. (2007). Does efficiency sensing unify diffusion and quorum sensing?. Nature Reviews Microbiology, 5(3), 230.

Hilton, A., Zhang, H., Yu, W., \& Shim, W. B. (2017). Identification and Characterization of Pathogenic and Endophytic Fungal Species Associated with Pokkah Boeng Disease of Sugarcane. The plant pathology joumal, 33(3), 238.

Ho, Y. N., Chiang, H. M., Chao, C. P., Su, C. C., Hsu, H. F., Guo, C. T., ... \& Huang, C. C. (2015). In planta biocontrol of soilborne Fusarium wilt of banana through a plant endophytic bacterium, Burkholderia cenocepacia 869T2. Plant and soil, 387(1-2), 295-306.

Holtsmark, I., Eijsink, V. G., and Brurberg, M. B. (2007). Bacteriocins from plant pathogenic bacteria. FEMS microbiology letters, 280(1), 1-7.

Huang, J., Su, Z., \& Xu, Y. (2005). The evolution of microbial phosphonate degradative pathways. Journal of molecular evolution, 61(5), 682-690.

Hwang, J., Chilton, W. S., \& Benson, D. M. (2002). Pyrrolnitrin production by Burkholderia cepacia and biocontrol of Rhizoctonia stem rot of poinsettia. Biological control, 25(1), 56-63.

Instituto Leibniz DSMZ-German Coleção de Microorganismos e Culturas Celulares, Alemanha, Nomenclatura procariótica atualizada [setembro 2017], (http://www.dsmz.de/bacterialdiversity/prokaryotic-nomenclature-up-to-date ) 
Ji, Xianling et al.(2010). Colonization of Morus alba L. by the plant-growth-promoting and antagonistic bacterium Burkholderia cepacia strain Lu10-1. BMC microbiology, 10(1), 243.

Jiao, Y., Yoshihara, T., Ishikuri, S., Uchino, H., \& Ichihara, A. (1996). Structural identification of cepaciamide A, a novel fungitoxic compound from Psendomonas cepacia D-202. Tetrahedron letters, 37(7), 1039-1042.

Joffe, A. Z. (1986). Fusarium species: their biology and toxicology. John Wiley \& Sons.

Ju, K. S., Doroghazi, J. R., \& Metcalf, W. W. (2014). Genomics-enabled discovery of phosphonate natural products and their biosynthetic pathways. Journal of industrial microbiology E biotechnology, 41(2), 345-356.

Jung, Boknam et al. (2018). Cooperative interactions between seed-borne bacterial and air-borne fungal pathogens on rice. Nature communications, 9(1), 31.

Kang, Y., Carlson, R., Tharpe, W., \& Schell, M. A. (1998). Characterization of genes involved in biosynthesis of a novel antibiotic from Burkholderia repacia BC11 and their role in biological control of Rhizoctonia solani. Applied and environmental microbiology, 64(10), 3939-3947.

Kim, Y. C., Tarr, A. W., Penfold, C. N. (2014). Colicin import into E. coli cells: a model system for insights into the import mechanisms of bacteriocins. Biochimica et Biophysica Acta (BBA)Molecular Cell Research, 1843(8), 1717-1731.

Kim, Y. S., Balaraju, K., \& Jeon, Y. H. (2017). Biological characteristics of Bacillus amyloliquefaciens AK-0 and suppression of ginseng root rot caused by Cylindrocarpon destructans. Journal of applied microbiology, 122(1), 166-179.

Kolter, R., \& Moreno, F. (1992). Genetics of ribosomally synthesized peptide antibiotics. Annual Reviews in Microbiology, 46(1), 141-161.

Lacava, P. T., Araújo, W. L., Marcon, J., Maccheroni, W., \& Azevedo, J. L. (2004). Interaction between endophytic bacteria from citrus plants and the phytopathogenic bacteria Xylella fastidiosa, causal agent of citrus-variegated chlorosis. Letters in applied microbiology, 39(1), 55-59.

Lagopodi, A. L., Ram, A. F., Lamers, G. E., Punt, P. J., Van den Hondel, C. A., Lugtenberg, B. J., \& Bloemberg, G. V. (2002). Novel aspects of tomato root colonization and infection by Fusarium oxysporum f. sp. radicis-lycopersici revealed by confocal laser scanning microscopic analysis using the green fluorescent protein as a marker. Molecular Plant-Microbe Interactions, 15(2), 172-179.

Lana, M. D. C., Dartora, J., Marini, D., \& Hann, J. E. (2012). Inoculation with Aqospirillum, associated with nitrogen fertilization in maize. Revista Ceres, 59(3), 399-405.

Lanubile, A., Ferrarini, A., Maschietto, V., Delledonne, M., Marocco, A., \& Bellin, D. (2014). Functional genomic analysis of constitutive and inducible defense responses to Fusarium verticillioides infection in maize genotypes with contrasting ear rot resistance. $B M C$ genomics, 15(1), 710. 
Lasca, C. C., Vechiato, M. H., Fantin, G. M., \& Kohara, E. Y. (2005). Efeito do tratamento químico de sementes de milho sobre a emergência e a produção. Arq. Inst. Biol., São Paulo, 72(4), 461-468.

Lea, P. J., \& Miflin, B. J. (2018). Nitrogen assimilation and its relevance to crop improvement. Annual plant reviews, 1-40.

Leslie, J. F., \& Summerell, B. A. (2008). The Fusarium laboratory manual. John Wiley \& Sons.

Lloubès, R., Cascales, E., Walburger, A., Bouveret, E., Lazdunski, C., Bernadac, A., \& Journet, L. (2001). The Tol-Pal proteins of the Escherichia coli cell envelope: an energized system required for outer membrane integrity?. Research in microbiology, 152(6), 523-529.

Lopes, L. D., Pereira e Silva, M. D. C., \& Andreote, F. D. (2016). Bacterial abilities and adaptation toward the rhizosphere colonization. Frontiers in microbiology, 7, 1341.

Lopes-da-Silva, Marcelo \& Sugayama, Regina \& Eduardo Rangel, Luis \& Carlos Ribeiro, Luis. (2015). Defesa vegetal: fundamentos, ferramentas, politicas e perspectivas.

Lucy, M.; Reed, E.; Glick, B.R. (2014). Applications of free living plant growth-promoting rbizobacteria. Antonie Van Leeuwenhoek, Wageningen,

Luvizotto, D.M. et al. (2010). Genetic diversity and plant-growth related features of Burkholderia spp. from sugarcane roots. World Journal of Microbiology and Biotechnology, 26(10), 1829-1836.

Macedo, R. et al. (2017). Potential worldwide distribution of Fusarium dry root rot in common beans based on the optimal environment for disease occurrence. PloS one, 12(11), e0187770.

Mackman, R. L., Ray, A. S., Hui, H. C., Zhang, L., Birkus, G., Boojamra, C. G., ... \& Laflamme, G. (2010). Discovery of GS-9131: Design, synthesis and optimization of amidate prodrugs of the novel nucleoside phosphonate HIV reverse transcriptase (RT) inhibitor GS9148. Bioorganic \& medicinal chemistry, 18(10), 3606-3617.

Madhaiyan, M., Saravanan, V. S., Jovi, D. B. S. S., Lee, H., Thenmozhi, R., Hari, K., \& Sa, T. (2004). Occurrence of Gluconacetobacter diazotrophicus in tropical and subtropical plants of Western Ghats, India. Microbiological research, 159(3), 233-243.

Maia, P. P., Rath, S., \& Reyes, F. G. R. (2009). Antimicrobianos em Alimentos de Origem Vegetal-Uma Revisão. Segurança Alimentar e Nutricional, 16(1), 49-64.

Mander, L., \& Liu, H. W. (2010). Comprehensive natural products II: Chemistry and Biology (Vol. 1). Elsevier.

Mano, Emy Tiyo (2011). Identificação de genes de Burkholderia sp. associados ao controle biológico de Pectobacterium carotovora. 101f. dissertação de (mestrado em Biotecnologia) Universidade de Mogi das Cruzes, São Paulo, 2011.

MAO, S., Lee, S. J., Hwangbo, H., Kim, Y. W., Park, K. H., Cha, G. S., ... \& Kim, K. Y. (2006). Isolation and characterization of antifungal substances from Burkbolderia sp. culture broth. Current microbiology, 53(5), 358-364. 
Marcon, J. Efeito de cana de açúcar geneticamente modificada sobre comunidades bacterianas. 2007 96p. (Doutorado em Biotecnologia) - Instituto de Ciências Biológicas, Iniversidade de São Paulo, 2007.

Marroquin-Guzman, M., \& Wilson, R. A. (2015). GATA-dependent glutaminolysis drives appressorium formation in Magnaporthe oryzae by suppressing TOR inhibition of cAMP/PKA signaling. PLoS pathogens, 11(4), e1004851.

Marshall, S. H., \& Arenas, G. (2003). Antimicrobial peptides: A natural alternative to chemical antibiotics and a potential for applied biotechnology. Electronic Journal of Biotechnology, 6(3), 271 284.

McGovern, R. J. (2015). Management of tomato diseases caused by Fusarium oxysporum. Crop Protection, 73, 78-92.

Medema, M. H., Blin, K., Cimermancic, P., de Jager, V., Zakrzewski, P., Fischbach, M. A., ... \& Breitling, R. (2011). antiSMASH: rapid identification, annotation and analysis of secondary metabolite biosynthesis gene clusters in bacterial and fungal genome sequences. Nucleic acids research, 39(suppl_2), W339-W346.

Medema, M. H., Kottmann, R., Yilmaz, P., Cummings, M., Biggins, J. B., Blin, K., ... \& CruzMorales, P. (2015). Minimum information about a biosynthetic gene cluster. Nature chemical biology, 11(9), 625.

Mendes, R., Pizzirani-Kleiner, A. A., Araujo, W. L., \& Raaijmakers, J. M. (2007). Diversity of cultivated endophytic bacteria from sugarcane: genetic and biochemical characterization of Burkholderia cepacia complex isolates. Applied and environmental microbiology, 73(22), 7259-7267.

Menéndez-Arias, L., Álvarez, M., \& Pacheco, B. (2014). Nucleoside/nucleotide analog inhibitors of hepatitis B virus polymerase: mechanism of action and resistance. Current opinion in virology, 8, 1-9.

Moffitt, M. C., \& Neilan, B. A. (2001). On the presence of peptide synthetase and polyketide synthase genes in the cyanobacterial genus Nodularia. FEMS Microbiology Letters, 196(2), 207214.

Moreira, F.S. et al. (2016). Functional abilities of cultivable plant growth promoting bacteria associated with wheat (Triticum aestivum L.) crops. Genetics and molecular biology, v. 39, n. 1, p. 111-121.

Müller, C. A., Oberauner-Wappis, L., Peyman, A., Amos, G. C., Wellington, E. M., \& Berg, G. (2015). Mining for nonribosomal peptide synthetase and polyketide synthase genes revealed a high level of diversity in the Sphagnum bog metagenome. Applied and environmental microbiology, 81(15), 5064-5072.

Nacamulli, C., Bevivino, A., Dalmastri, C., Tabacchioni, S., \& Chiarini, L. (1997). Perturbation of maize rhizosphere microflora following seed bacterization with Burkholderia cepacia MCI 7. FEMS Microbiology Ecology, 23(3), 183-193. 
Nandineni, M. R., Laishram, R. S., \& Gowrishankar, J. (2004). Osmosensitivity associated with insertions in $\arg \mathrm{P}$ (iciA) or glnE in glutamate synthase-deficient mutants of Escherichia coli. Journal of bacteriology, 186(19), 6391-6399.

Neves, A. A. C. 2011. Identificação de genes de Burkholderia sp. associados ao antagonismo a microrganismo fitopatogênicos., 62f. dissertação de (mestrado em Biotecnologia) Universidade de Mogi das Cruzes, São Paulo, 2011.

Nowack, B. (2003). Environmental chemistry of phosphonates. Water research, 37(11), 2533-2546.

OECD/Food and Agriculture Organization of the United Nations (2015), OECD-FAO Agricultural Outlook 2015, OECD Publishing, Paris. bttp://dx.doi.org/10.1787/agr_outlook-2015en

Paik, S. J., Damm, A., Manzi, J., Dahan, M., Bassereau, P., Margeat, E., \& Levy, D. (2018). Functional and Structural Studies of Interplay between an ABC Transporter and its Surrounding Membrane Environment. Biophysical Journal, 114(3), 188a-189a.

Parke, J. L., \& Gurian-Sherman, D. (2001). Diversity of the Burkholderia cepacia complex and implications for risk assessment of biological control strains. Annual review of phytopathology, 39(1), 225-258.

Parke, J. L., Rand, R. E., Joy, A. E., \& King, E. B. (1991). Biological control of Pythium dampingoff and Aphanomyces root rot of peas by application of Pseudomonas cepacia or P. fluorescens to seed. Plant disease, 75(10), 987-992.

Parker, W. L., Rathnum, M. L., Seiner, V., Trejo, W. H., Principe, P. A., \& Sykes, R. B. (1984). Cepacin A and cepacin B, two new antibiotics produced by Pseudomonas cepacia. The Journal of antibiotics, 37(5), 431-440.

Penfold, C. N., Li, C., Zhang, Y., Vankemmelbeke, M., \& James, R. (2012). Colicin A binds to a novel binding site of TolA in the Escherichia coli periplasm.

Pereira, G. S. et al.( 2017). Selection of maize inbred lines and gene expression for resistance to ear rot. Genetics and Molecular Research, 16(3).

Pérez-Montaño, F., Alías-Villegas, C., Bellogín, R. A., Del Cerro, P., Espuny, M. R., JiménezGuerrero, I., ... \& Cubo, T. (2014). Plant growth promotion in cereal and leguminous agricultural important plants: from microorganism capacities to crop production. Microbiological research, 169(5-6), 325-336.

Perin, L., Martinez-Aguilar, L., Paredes-Valdez, G., Baldani, J. I., Estrada-De Los Santos, P., Reis, V. M., \& Caballero-Mellado, J. (2006). Burkholderia silvatlantica sp. nov., a diazotrophic bacterium associated with sugar cane and maize. International Journal of Systematic and Evolutionary Microbiology, 56(8), 1931-1937.

Peters, P., Galinski, E. A., \& Trüper, H. G. (1990). The biosynthesis of ectoine. FEMS microbiology letters, 71(1-2), 157-162.

Punja, Z. K., \& Utkhede, R. S. (2003). Using fungi and yeasts to manage vegetable crop diseases. TRENDS in Biotechnology, 21(9), 400-407. 
Quan, C. S., Zheng, W., Liu, Q., Ohta, Y., \& Fan, S. D. (2006). Isolation and characterization of a novel Burkholderia cepacia with strong antifungal activity against Rhiroctonia solani. Applied microbiology and biotechnology, 72(6), 1276-1284.

Quecine, M. C. (2010). Aspectos biotecnológicos da interação entre bactérias e cana-de-açúcar (Saccharum sp., L.)(Doctoral dissertation, Universidade de São Paulo).

Quecine, M. C., Kidarsa, T. A., Goebel, N. C., Shaffer, B. T., Henkels, M. D., Zabriskie, T. M., \& Loper, J. E. (2016). An Interspecies Signaling System Mediated by Fusaric Acid Has Parallel Effects on Antifungal Metabolite Production by Pseudomonas protegens Strain Pf-5 and Antibiosis of Fusarium spp. Applied and environmental microbiology, 82(5), 1372-1382.

Raaijmakers, J. M., Paulitz, T. C., Steinberg, C., Alabouvette, C., \& Moënne-Loccoz, Y. (2009). The rhizosphere: a playground and battlefield for soilborne pathogens and beneficial microorganisms. Plant and soil, 321(1-2), 341-361.

Rassam, P., Housden, N., \& Kleanthous, C. (2018). Depicting the Translocation Process of the Protein Antibiotic Colicin E9 through OmpF. Biophysical Journal, 114(3), 188a.

Richards, N. G., Humkey, R. N., Li, K., Meyer, M. E., \& de Sintjago, T. C. C. (2010). Tunnels and Intermediates in the Glutamine-Dependent Amidotransferases.

Riley, M. A., \& Wertz, J. E. (2002). Bacteriocin diversity: ecological and evolutionary perspectives. Biochimie, 84(5-6), 357-364.

Romero, D., de Vicente, A., Rakotoaly, R. H., Dufour, S. E., Veening, J. W., Arrebola, E., ... \& Pérez-García, A. (2007). The iturin and fengycin families of lipopeptides are key factors in antagonism of Bacillus subtilis toward Podosphaera fusca. Molecular Plant-Microbe Interactions, 20(4), 430-440.

Rossetto, P. B. Interação entre cana de açúcar e bactérias associadas. 2008. 148 p. Tese (doutorado em Agronomia) Escola superior de Agricultura "Luiz de Queiroz", Universidade de São Paulo. 2008.

Rossetto, R.; \& Santiago, A. D. (2007). Adubação: resíduos alternativos. Brasilia, DF: EMBRAPA. Disponível em: http://www.agencia.cnptia.embrapa.br/gestor/cana-deacucar/arvore/CONTAG01 39 711200516717.html. Acesso em: 11 de abril de 2018.

Sahu, Binod B. et al. (2017). Investigation of the Fusarium virguliforme Transcriptomes Induced during Infection of Soybean Roots Suggests that Enzymes with Hydrolytic Activities Could Play a Major Role in Root Necrosis. PloS one, 12(1), e0169963.

Saikia, S. P., Bora, D., Goswami, A., Mudoi, K. D., \& Gogoi, A. (2012). A review on the role of Azospirillum in the yield improvement of non leguminous crops. African Journal of Microbiology Research, 6(6), 1085-1102.

Sambrook, J., \& Russell, D. W. (2001). Molecular cloning: a laboratory manual. 2001.

Sandanakirouchenane, A., Haque, E., \& Geetha, T. (2017). Recent Studies on N2 Fixing Burkbolderia isolates as a Biofertilizer for the Sustainable Agriculture. Int. J. Curr. Microbiol. App. Sci, 6(11), 2780-2796. 
Schöner, T. A., Gassel, S., Osawa, A., Tobias, N. J., Okuno, Y., Sakakibara, Y., ... \& Bode, H. B. (2016). Aryl polyenes, a highly abundant class of bacterial natural products, are functionally related to antioxidative carotenoids. ChemBioChem, 17(3), 247-253.

Schouten, A., van den Berg, G., Edel-Hermann, V., Steinberg, C., Gautheron, N., Alabouvette, C., ... \& Raaijmakers, J. M. (2004). Defense responses of Fusarium oxysporum to 2, 4diacetylphloroglucinol, a broad-spectrum antibiotic produced by Psendomonas fluorescens. Molecular Plant-Microbe Interactions, 17(11), 1201-1211.

Seifert, H. S., Chen, E. Y., SO, M., \& Heffron, F. (1986). Shuttle mutagenesis: a method of transposon mutagenesis for Saccharomyces cerevisiae. Proceedings of the National Academy of Sciences, 83(3), 735-739.

Shuping, D. S. S.; Eloff, J. N.(2017). The use of plants to protect plants and food against fungal pathogens: A review. African Journal of Traditional, Complementary, and Alternative Medicines, 14(4), 120.

Sijam, K. A. M. A. R. U. Z. A. M. A. N., and Dikin, A. (2005). Biochemical and physiological characterization of Burkholderia cepacia as biological control agent. Int J Agric Biol, 7, 385-388.

Silva, H. S. A., Romeiro, R. S., Carrer Filho, R., Pereira, J. L. A., Mizubuti, E. S. G., \& Mounteer, A. (2004). Induction of systemic resistance by Bacillus cereus against tomato foliar diseases under field conditions. Journal of Phytopathology, 152(6), 371-375.

Soria, S., Alonso, R., \& Bettucci, L. (2012). Endophytic bacteria from Pinus taeda L. as biocontrol agents of Fusarium circinatum Nirenberg \& O'Donnell. Chilean Journal of Agricultural Research, 72(2), 281.

Souza, E. L. D., Silva, C. A. D., \& Sousa, C. P. D. (2005). Bacteriocins: molecules of fundamental impact on the microbial ecology and potential food biopreservatives. Brazilian Archives of Biology and Technology, 48(4), 559-566.

Stöveken, N., Pittelkow, M., Sinner, T., Jensen, R. A., Heider, J., \& Bremer, E. (2011). A Specialized Aspartokinase Enhances the Biosynthesis of the Osmoprotectants Ectoine and Hydroxyectoine in Pseudomonas stutzeri A1501. Journal of bacteriology, 193(17), 4456-4468.

Struger, J., Van Stempvoort, D. R., \& Brown, S. J. (2015). Sources of aminomethylphosphonic acid (AMPA) in urban and rural catchments in Ontario, Canada: Glyphosate or phosphonates in wastewater?. Environmental pollution, 204, 289-297.

Suárez-Moreno, Z. R., Caballero-Mellado, J., Coutinho, B. G., Mendonça-Previato, L., James, E. K., \& Venturi, V. (2012). Common features of environmental and potentially beneficial plantassociated Burkholderia. Microbial Ecology, 63(2), 249-266.

Tamura, K., Peterson, D., Peterson, N., Stecher, G., Nei, M., \& Kumar, S. (2011). MEGA5: molecular evolutionary genetics analysis using maximum likelihood, evolutionary distance, and maximum parsimony methods. Molecular biology and evolution, 28(10), 2731-2739.

Tan, R. X., \& Zou, W. X. (2001). Endophytes: a rich source of functional metabolites. Natural product reports, 18(4), 448-459. 
Tan, S., Jiang, Y., Song, S., Huang, J., Ling, N., Xu, Y., \& Shen, Q. (2013). Two Bacillus amyloliquefaciens strains isolated using the competitive tomato root enrichment method and their effects on suppressing Ralstonia solanacearum and promoting tomato plant growth. Crop Protection, 43, 134-140.

Tremacoldi, C.R. (2010). Principais doenças fúngicas da pimenteira-do-reino no Estado do Pará e recomendações de controle. Embrapa Amazônia Oriental-Documentos (INFOTECA-E).

Tyrrell, J., Whelan, N., Wright, C., Sá-Correia, I., McClean, S., Thomas, M., \& Callaghan, M. (2015). Investigation of the multifaceted iron acquisition strategies of Burkholderia cenocepacia. Biometals, 28(2), 367-380.

Vanoni, M. A., \& Curti, B. (1999). Glutamate synthase: a complex iron-sulfur flavoprotein. Cellular and Molecular Life Sciences CMLS, 55(4), 617-638.

Vial, Ludovic et al. (2007). Burkholderia diversity and versatility: an inventory of the extracellular products. Journal of microbiology and biotechnology, 17(9), 1407-1429.

Walburger, A., Lazdunski, C., \& Corda, Y. (2002). The Tol/Pal system function requires an interaction between the C-terminal domain of TolA and the $\mathrm{N}$-terminal domain of TolB. Molecular microbiology, 44(3), 695-708.

Wei, H. L., \& Zhang, L. Q. (2006). Quorum-sensing system influences root colonization and biological control ability in Pseudomonas fluorescens 2P24. Antonie Van Leeunenboek, 89(2), 267280.

Xu, L. M., Liang, Y. F., Ye, Q. D., Yang, Z., Foley, M., Snyder, S. A., . \& Wong, H. N. (2012). Organic Chemistry-Breakthroughs and Perspectives.

Zarad, S. I., Nimkar, N. R., Desai, K. R., Solanki, M. S., Gandhi, D. M., Gandhi, H. M., ... \& Suraliwala, M. N. (2016). Measurement of Uncertainty Associated with Quantification of Ethephon. Indian Journal of Science and Technology, 9(45).

Zhang, Y., Li, C., Vankemmelbeke, M. N., Bardelang, P., Paoli, M., Penfold, C. N., \& James, R. (2010). The crystal structure of the TolB box of colicin A in complex with TolB reveals important differences in the recruitment of the common TolB translocation portal used by group A colicins. Molecular microbiology, 75(3), 623-636.

Zhou, W., Shi, W., Xu, X. W., Li, Z. G., Yin, C. F., Peng, J. B., ... \& Yang, J. (2018). Glutamate synthase MoGlt1-mediated glutamate homeostasis is important for autophagy, virulence and aconidiation in the rice blast fungus. Molecular plant pathology, 19(3), 564-578. 